\title{
Geochemistry acidic water of Banyupait river effect seepage of crater water Ijen volcano, Asembagus, Situbondo, East Java, Indonesia
}

\author{
DF. Yudiantoro ${ }^{\text {a* }}$, B. Agus Irawan ${ }^{\text {b }}$ I. Paramita Haty ${ }^{a}$, DS. Sayudic ${ }^{c}$ A. Suproborini ${ }^{d}$, \\ S. Bawaningrum ${ }^{\mathrm{a}}$, P. Ismaya ${ }^{\mathrm{a}}, \mathrm{M}$. Abdurrachman ${ }^{\mathrm{e}}, \mathrm{I}_{\text {. Takashima }}{ }^{\mathrm{f}}$ \\ ${ }^{\text {a }}$ Geology Engineering Department of UPN Veteran Yogyakarta \\ ${ }^{\mathrm{b}}$ Environmental Engineering Department of UPN Veteran Yogyakarta \\ ${ }^{\mathrm{c}}$ Geology Agency \\ ${ }^{d}$ Pharmacy Study Program of PGRI Madiun University \\ ${ }^{\mathrm{e}}$ Geology Engineering Department of ITB Bandung \\ ${ }^{\mathrm{f}}$ Geological Department of Akita University Japan
}

\begin{abstract}
The Ijen volcano has Pleistocene age (294.00 $\pm 0.03 \mathrm{Ma})$, and this stratovolcano was very acidic crater water with a $\mathrm{pH}$ of $0-1$. The acidic crater water seeps into the Banyupait river flow. Asembagus is a research area located on the northern slope of the Ijen volcano, and the Banyupait River drains this. The acidic river water flows from the Ijen Crater Lake, so the $\mathrm{pH}$ of the water river was very acidic. This study used several different analytic methodologies with some previous researchers, namely using the method of geological mapping, pH measurement, spectrophotometry, IRMS (Isotope Ratio Mass Spectrometer), and the technique of Induced Coupled Mass Spectrometry (ICP-MS). Besides, the petrographic analysis is used to determine the composition of rock minerals due to rocks interacting with acidic water. Banyupait River water in the Asembagus area has a $\mathrm{pH}$ of river water around 3-7.3, $\mathrm{SO}_{4}(220-683 \mathrm{ppm})$, and the type of water is meteoric water. Also, concentrations of $\mathrm{Ca}, \mathrm{K}, \mathrm{Mg}$ in the west Banyupait river irrigation water flow showed higher levels when compared to the eastern Banyupait River water flow. Likewise, REE elements from the Asembagus region showed lower concentrations compared to Ijen Crater water. This change in the level of chemical elements is caused by the acidity of the Banyupait River being diluted or mixed with water from other water. However, the spring was not affected by acidic water. The process of acidic water interaction with rocks can also be observed from rocks traversed by the Banyupait River flow. Chalcedony and hematite replace the primary minerals of basaltic rocks. This research is expected to improve the quality of water needed by the Asembagus community so that people can live healthily.
\end{abstract}

Keywords: stratovolcano; crater; acid; REE; health

\section{Introduction}

Indonesia has around 129 active volcanoes or $13 \%$ of the total volcanoes in the world because Indonesia located at the confluence of the Eurasian Plate, the Indo-Australian Plate, and the Pacific Plate. The research located in Asembagus Situbondo, the northern slope of the Ijen Volcano. Ijen Volcano is very active, and the eruption center often moves. Eruptions that have occurred were in 1796, 1817, 1917, 1936, 1952, and 1993, 2000 and 2001. The watercolor of the crater lake was light green, which indicates very acidic water, and some researchers such as: $[1,2,3,4,5]$ also stated that the $\mathrm{pH}$ value of shallow crater water $(0-1)$. Based on its morphology, the stream of the Banyuputih River consists of tributaries: Banyupait, Blawan, Kalisat, Sengon, Banyuputih 1, and Banyuputih 2 Rivers to the north of Blawan [6]. The Banyupait River flows through the Asembagus area. It has a population of around 660,702 people with an agricultural region of 60,597.34 ha. Some Asembagus agricultural areas are fed by this Banyupait River acidic water, 
especially the western Banyupait River, while the east Banyupait River water flows continuously towards the sea. For this reason, it was necessary to do this research, which intended to determine the distribution of chemical elements in the Banyupait River acid water, so that the concentration and water characteristics of the Banyupait River can be used to monitor public health Asembagus.

\subsection{Geology of Ijen Volcano}

The Ijen Caldera Complex (ICC) was first mapped by [7], which morphologically the ICC (2386 m) was a round-shaped caldera depression. Inside the crater, there was the Ijen Crater and Merapi Volcano [8], while, according to [9] are two types of volcanoes, namely: rim caldera and intra caldera volcano. [10] states that the Ijen Crater was elliptical due to the displacement of the crater pipe, which was a large stratovolcano [5, 11, 12]. Besides, this Ijen Crater was a lake with a size of $910 \mathrm{~m}$ x $600 \mathrm{~m} 148$ with a depth of $200 \mathrm{~m}$. The ICC is formed in the Pleistocene period [13] based on the period of cone collapse, and the ICC stratigraphy is divided into three groups, e.i. Pre-caldera volcanic deposits, caldera, and Post-caldera.

\subsubsection{Pre-caldera volcanic deposits}

The Pre-caldera volcanic deposits of Upper Pleistocene (294.00 $\pm 0.03 \mathrm{Ma})$ were revealed both on the north wall of the caldera, and in the old volcanic morphology south of the caldera. These two old morphologies are the remains of the cone of Old Ijen Volcano. The Pre-caldera volcanic deposits include pyroclastic flow deposits and lava flows. The lava flows revealed at the base of the Ijen Crater, which was $297.00 \pm 0.03 \mathrm{Ma}$ (K-Ar method) with a composition of basalt, andesite, and dacite [13].

\subsubsection{Caldera volcanic deposits}

This caldera volcanic deposit consists of ignimbrite and pyroclastic fall deposits, which spread out of the caldera. They cover the entire north side of the caldera. The ignimbrite of caldera volcanic deposits are characterized by the interbedded of pyroclastic flow sequences, pyroclastic fall deposits, and lahars. The pyroclastic fall deposits of caldera formations are fragmented pumice and are inserted by pyroclastic flows and pyroclastic surges. The caldera formation occurs between 300,000 (Pre-caldera deposits youngest) and 50,000 (post-caldera deposits oldest) years ago [6] through the collapse of the Old Ijen stratovolcano [6, 14]. The non-volcanic structure then developed inside the caldera [7], as a lake, which was emptied 50,000 years ago, due to a fault system that cut the walls of the northern Kendeng caldera [14] (Figure 1).

\subsubsection{Post-caldera volcanic deposits}

The appearance of the Belawan lake sediment deposits on the floor of the Ijen Caldera marks the beginning of Post-caldera sedimentation. In Blawan, these lake deposits are characterized by alternating shale, sand, and travertine deposits. Besides, the river deposits are found cross-bedding and parallel lamination structures covered by lahar deposits. Based on the distribution pattern of the eruption center, the post-caldera volcanic deposits can be grouped into two parts, namely the sides and in the caldera. The volcanic cones on the sides of the caldera include Mt. Jampit (Pendil), Mt. Ringgih, Mt. Suket, Mt. Rante, Mt. Merapi, and Mt. Ijen. In contrast, the inside of the caldera is dominated by cinder cones such as Mt. Widodaren, Mt. Cilik, Mt. Gempol, Mt. Kawahwurung, Mt. Anyar, Mt. Lingker, Mt. Mlaten, Mt. Cemara, and Mt. Gendingwaluh with several composite cones (Mt. Blau, Mt. Pawenen, Mt. Kukusan, and Mt. Genteng), Mt. Geleman dome and pyroclastic cone of Mt. Papak. The Post-caldera volcanic deposits vary significantly in type, consisting of pyroclastic flows and falls, pyroclastic surges, lahar, debris avalanche, and lava flows.

Similarly, the type of eruptions, such as magmatic, phreatomagmatic, phreatic, from strombolian to plinian. In comparison, the Post-caldera volcanic center consists of several separate volcanic cones (Figure 1). They spread in the southern part of the caldera. About 25,000 years ago, 13 intra caldera cones were scattered in the E-W direction, starting from the Mlaten to the active Ijen Crater $[6,15,16]$. This direction was in line with the tectonic alignment identified by [17]. Then this volcano erupts with high Ca basaltic- 
andesite magma composition, while the intra caldera volcanoes erupt with basaltic-andesite to low-dacitic magma composition $[6,15,18,19,20]$. According to $[1,21]$, this active stratovolcano has an andesitic to andesitic basalt composition. Whereas, based on the geochemical analysis of several lavas from Ijen and Mt. Anyar Craters conducted by [22], explain in general that these lavas can be classified into basalt, andesite basaltic and basaltic trachyandesite with a medium-high $\mathrm{K}$ calk-alkali series. [19] refers to the position of the volcanoes as different from the $\mathrm{Ca}$ fractionation trend, indicating that the chemical variations of this volcanic complex may be related to different sub-volcanic structures or reservoir depths. $[11,12]$ mention Ijen volcanic rocks with basaltic composition, basaltic, andesitic, and dacite $[6,15,18$, 20]. Besides, according to Brouwer (in [14]), hyperstene augite andesite was the Pleistocene age [23]. [24] explained that the development of magmatism on the Java island during Tertiary to Quaternary experienced chemical changes, i.e., changes in magma affinity which shifted from the point of low $\mathrm{K}$ tholeiitic island arc (Tertiary volcanic arc) to calk-alkali series (Quaternary Sunda Arc) which Ijen Volcanoes are formed.

In the ICC, there are three normal faults which can be grouped into two deformation periods of fault formation. A graben structure marked the initial phase, and the final stage announced by the presence of Blawan and Jampit faults. The graben structure Pedati formed after the Ijen Caldera. The movement of the Pedati fault graben was younger than the unit ignimbrite the formation of the caldera and older than the sediment of Blawan Lake (50,000 years). The final phase involves the movement of the formation of the Blawan and Jampit faults. The movement of the Blawan fault occurred after the eruption of the young lava flows of Blau Volcano and before the deposition of the scoria pyroclastic from lower ICC. Jampit fault is characterized by a fault scarp on the lava flow of Jampit cone. Around the Cemara cone, the Jampit fault is covered by pyroclastic-flow deposits of the Suket Volcano (37,900 \pm 1850 years), and pyroclastic scoria deposits in the ICC, so according to [13] it is between 37,000 to 45,000 years. [7] states that Blau Cone (1774 $\mathrm{m}$ asl.) was the residual debris of Strato Old Ijen Volcano. Three units of lava flows were very clear erupted by Blau Volcano, the composition of the older lava flows were basalt, acid andesite, and the younger was acidic andesite lava flows. According to [7], the caldera must be formed after the eruption of the young lava flows of Blau Cone.

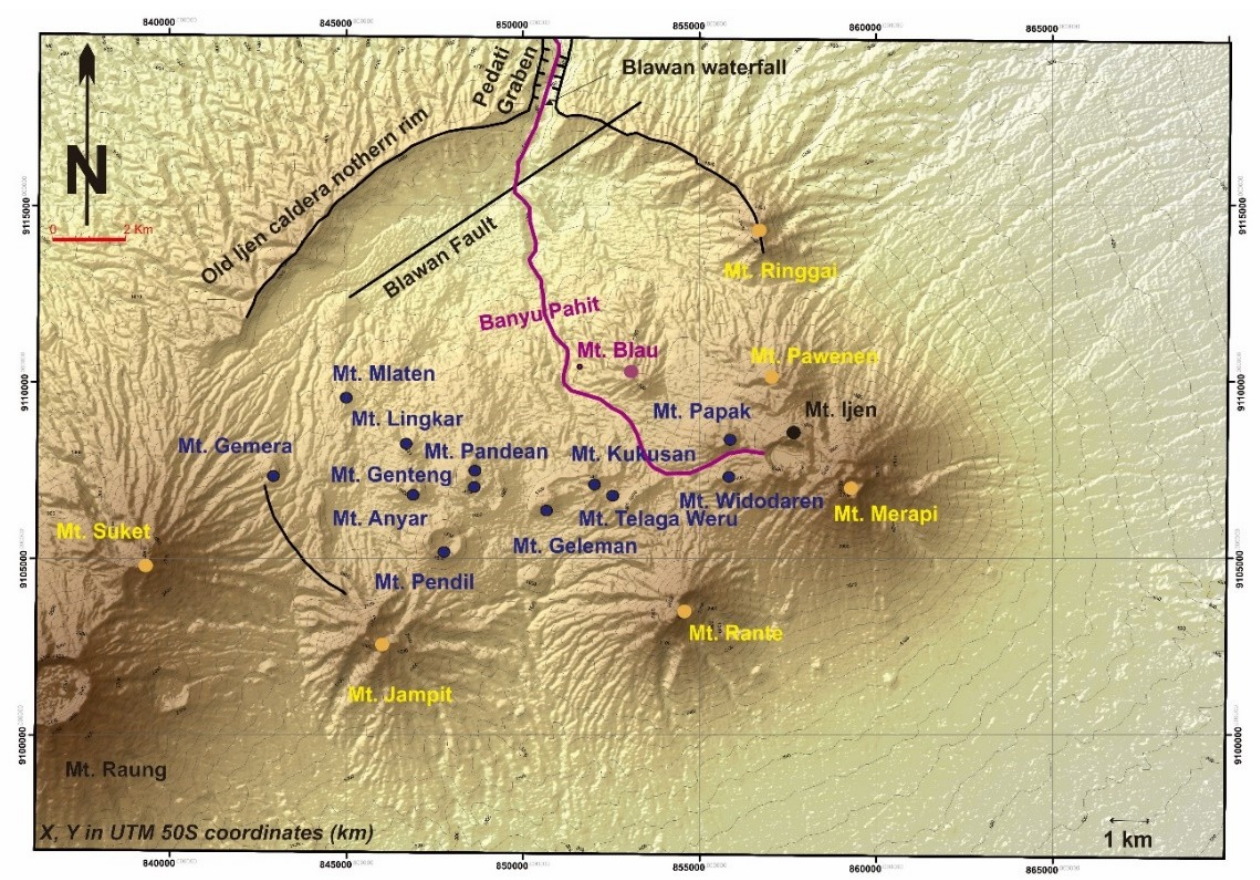

Figure 1. Map showing Pre-caldera Ijen and active volcanic formations and faults (modified from [23]). 


\subsection{Eruption History}

$[6,15]$ studied rocks found in the Ijen Crater, i.e., tephra deposits (scoria, ash, pumice, bombs), volcaniclastic flows, and pillow lava that can only be seen in the crater. $[11,12,22]$ explain that these stratovolcanoes each eruption center produces various eruption products, such as lava, pyroclastic flow, and pyroclastic fall. The Ijen eruption recorded in history is in the form of phreatic eruptions originating from the central crater [1]. The explosion of Ijen Volcano emits gas, pyroclastic material consisting of lapilli, ash, and volcanic bombs, all of which were pumiceous. The Ijen Volcano at $\sim 24,450 \mathrm{BP}$ entered a destructive phase with a massive peak explosion, and lava flows to the south [6,15]. Over the past two decades, this volcano has experienced many phreatic eruptions and produced pyroclastic fall deposits consisting of ash, fragments, and sulfur particles. The first eruption of the Ijen Volcano is recorded in 1796 $[14,25,26]$. Then on January 15,1817 , the volcano entered the eruption phase, with the biggest eruption occurring in late January [14, 25, 26]. Whereas [8] guesses the possibility of the eruption of 1817, most of the lake water is flowed by the Banyupait River. Subsequent activities noted that in 1917 [8], there was a rapid decline in water levels in lakes after the earthquake in Bondowoso, Java [14, 26, 27,]. [10] considers eruptions in crater lakes and phreatic eruptions on February 25 and March 13. This phreatic eruption also occurred on 5-25 November 1936 [10], and produced lahar, such as in 1796 and 1817. Increased Ijen volcanic activity is characterized by the emergence of gas bubbles and a sudden rise in temperature. Before the eruption, in March 1917, the temperature of Ijen crater water was $15^{\circ} \mathrm{C}$ at the end of 1917 . However, in $1925,1934,1936$, and 1956, there were strong eruptions that erupted, water, and mud to reach tens of meters high. Before the February 1921 eruption, the temperature of the crater increased to $50^{\circ} \mathrm{C}$ [28]. The $1 \mathrm{~km}$ high explosion of smoke and the sound of the avalanches heard from Sempol occurred on April 22, 1952, and in the crater, a $7 \mathrm{~m}$ high eruption occurred. This eruption is almost the same as the 1936 eruption (Hadikusumo, 1950-1957 in [29,30]. Moments before the 1997 explosion, there was a change in the color of the crater lake. The increase in Ijen Crater activity is also observed in early April 1999, which showed an increase in seismic activity, so that on 12 April 1999, it was declared alert. In May 1999, shallow volcanic earthquakes dominated events, and on June 23, a small eruption is recorded. On 28 June 1999, two recorded eruptions [28]. This phreatic eruption last occurred in 1999 [31, 32]. [30] explains that the 1990s and early 2000s were phreatic eruptions, whereas the current condition of the crater as a volcanic activity centered on the rhyolitic dome [16] was about $100 \mathrm{~m}$ in diameter and $20 \mathrm{~m}$ high, which was the location of many high-temperature fumaroles [33].

\section{Methods}

\subsection{Study Area}

The morphology of the study area was undulating hills to the coastal plain, which is located in the Situbondo Asembagus region (Figure 2), with a population of 2013 has reached 660.702 people. The research area includes Asembagus, Banyuputih, and Jangkar. Altitude area ranged from $0 \mathrm{~m}$ to the north and an altitude of 50-800 $\mathrm{m}$ in the south, which was the northern slopes of the foothills of the Ijen volcanic complex and had an annual temperature $24.7^{\circ} \mathrm{C}-27.9^{\circ} \mathrm{C}$. Groundwater surface around $10-30 \mathrm{~m}$ and the soil layer was volcanic ash and weathered alluvial type soil, regosol, gleysol, renzine, grumosol, mediterranean, latosol, and andosol. Based on the climate division, according to [34], are in the climate types $\mathrm{E}$ and $\mathrm{F}$, which were slightly dry and dry areas.

The dry months are the months with average rainfall in one month less than $60 \mathrm{~mm} / \mathrm{month}$. In contrast, the wet months are the months with average rainfall in a month of more than $100 \mathrm{~mm} / \mathrm{month}$. The average monthly rainfall of $60-100 \mathrm{~mm} / \mathrm{month}$ is ignored. Most of the fertile soil fed by water from the Banyupait River contaminated waste from the crater lake, which is very acidic, about $40 \mathrm{~km}$ to the south. This lake has a $\mathrm{pH}$ below 0.3 and contains around $1500 \mathrm{mg} / \mathrm{F}$, while river water ranges between 2.5 and 4.5 , and includes 5 to $14 \mathrm{ppm} \mathrm{F}$ at the entry point of irrigation, which is also used for bathing and washing. During 
the dry season (April to October), all waters discharged into the irrigation network through the sluice system, while the excess water during the rainy season (November to March) is directed into the sea through the original riverbed. It is estimated that, on average, $2800 \mathrm{ppm} \mathrm{F}$ is discharged into irrigation areas per day [3].

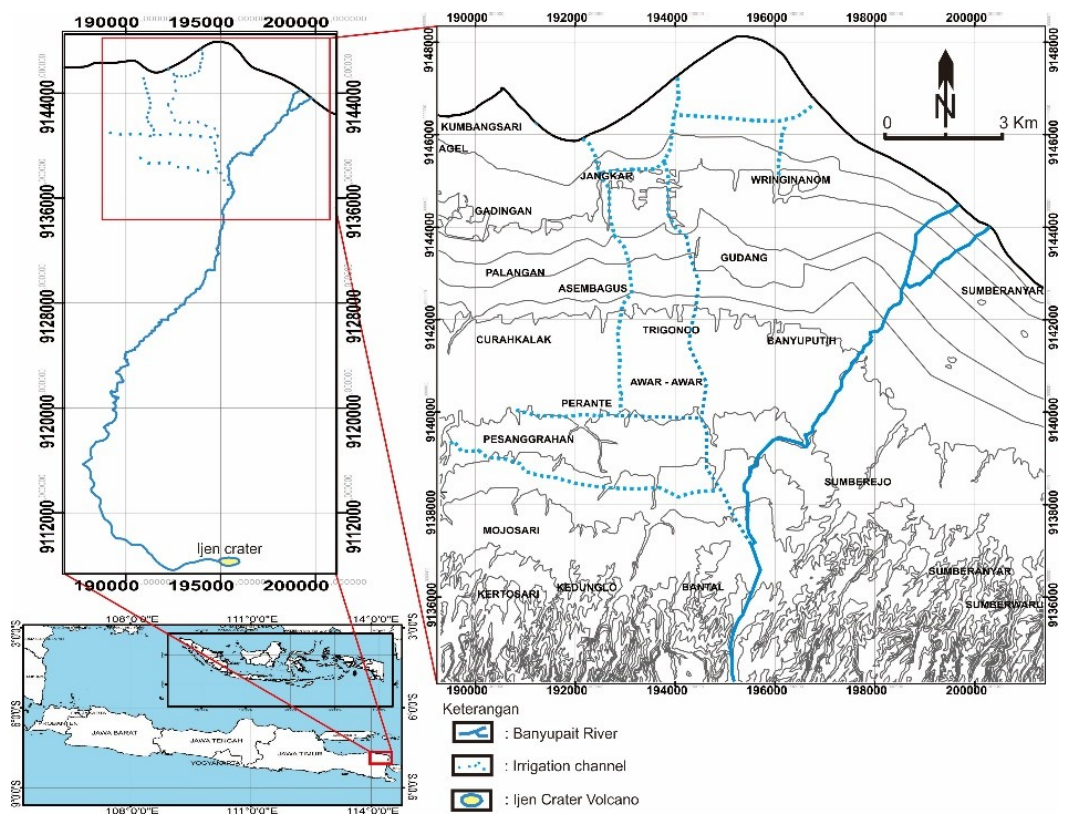

Figure 2. Map of the location of the Asembagus area, which is a research area.

\subsection{Analysis Tools}

This research aims to study the behavioral characteristics of the chemical elements of the Banyupait River water, which is influenced by the acid water of the Ijen Crater and explore the water characteristics around the Banyupait River, such as springs and wells water. Besides this, the Banyupait River water certainly has fascinating aspects, because the acidity of the water was very low due to the seepage of Ijen Crater Lake, so during the trip to the estuary, the river will experience changes in the concentration of REE elements. Infiltration of Ijen Crater water in the Banyupait River has been going on for a very long time so that it will affect the concentration of the surrounding water. Besides that, the water was used by residents for agriculture or for some residents to fulfill their daily needs. To study the characteristics of the geochemistry of Asembagus, so the laboratory analysis was needed, such as $\mathrm{pH}$ measurement and the chemical analysis of water using methods: spectrophotometry, IRMS (Isotope Ratio Mass Spectrometer), Induced Coupled Mass Spectrometry (ICP-MS) method. Whereas, to determine the composition of the rock minerals, we use a petrographic thin section analysis. This chemical analysis of water is carried out on several water samples originating from the Banyupait River water, well and spring water.

Measurement of water $\mathrm{pH}$ is carried out to determine the acidity of rivers, spring, and wells located around the Banyupait River. Samples taken were 15 samples of river water, 24 samples from wells, and 1 sample of spring. Meanwhile, to study water geochemistry, nine water samples were taken. In contrast, the analysis of $\mathrm{SO}_{4}$ content is used to determine the concentration of $\mathrm{SO}_{4}$ in water that has an acidic $\mathrm{pH}$. Analysis of $\mathrm{SO}_{4}$ and cation-anions content using spectrophotometric methods. The isotope ${ }^{18} \mathrm{O}$ and $\mathrm{D}$ analysis are performed on nine samples using the IRMS method (Isotope Ratio Mass Spectrometer), and Induced Coupled Mass Spectrometry (ICP-MS) is used to determine the distribution REE changes from upstream of the Banyupait River to the coast or estuary. Before the analysis of isotopes and REE, water is filtered first with a $40 \mu \mathrm{m}$ sieve. The REE analysis is conducted on nine samples, whereas to find out the 
mineral composition of rocks using a petrographic thin section analysis performed on rock samples, which are considered to represent the rock of the study area.

\section{Results}

\subsection{Geology Asembagus}

Geomorphologically the research area includes coastal plains, volcanic foot plains, and undulating hills. The coastal plain consists of the coastal regions with an altitude of $0 \mathrm{~m}$ spread over the northern part of the study area, i.e., Pesisir, Pondok Langgar, until Sukorejotimur (Figure 3). The rock constituent of this region is separated from the alluvial deposits of sand beach. Foot plain was a morphological formation compiled by volcanic lahar breccia from the Bogor Formation, and this area includes Mojosari, Karangtengah, Gedangan, Banyuputih to Sekarputih. This area has a height between 0-50 m, while the undulating hills morphology has a height of 50-800 m, which is arranged by flow pyroclastic deposits from old Ijen (Figure 4).

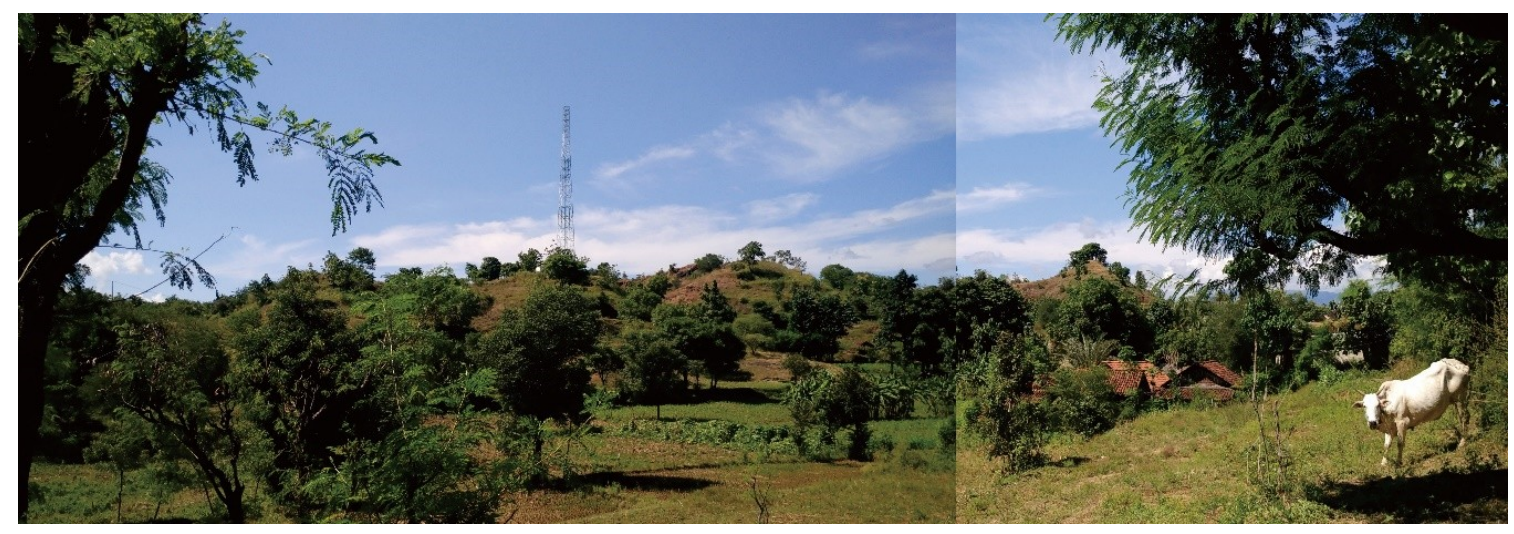

Figure 3. The appearance of the morphology of the northern coastal plain of the study area and Mount Ijen in the south.

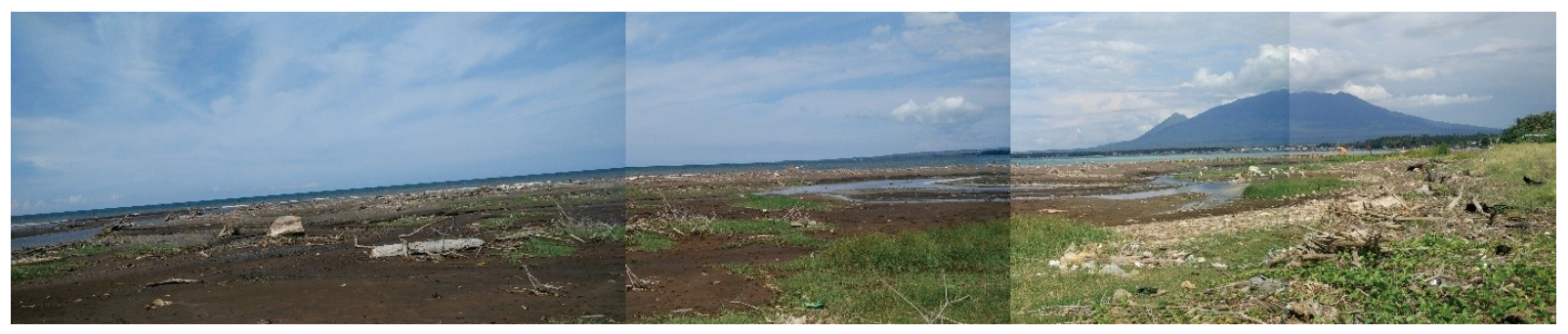

Figure 4. The appearance of undulating hills morphology compiled by pyroclastic breccia deposits.

The lithology of the study area, according to [35], was composed of Old Ijen volcanic rocks (Old Quaternary Volcanic Rock), which are thought to be Pleistocene, the Holocene and alluvium Bogor Formations (Young Quaternary volcanoes) which include river deposits, coastal deposits, and delta sediments. Old volcanic rocks consist of volcanic breccia, pumice breccia, tuff, and basalt lava, while the Bogor Formation rock consists of alternating between various material breccias, pumice breccia, tuffaceous sandstones, and sandstones. The mapping results in this research area indicate that the study area was composed of rock units from the order of old to young: Old Ijen pyroclastic breccias, Bogor lava breccia, 
and alluvial sediment of rivers and beaches (Figure 11). The Old Ijen pyroclastic flows rock unit revealed in the study area includes: Mt. Banter, Bantal to the east (Pandre).

The lahar breccia of the Bogor Formation, which is an epiclastic sediment spread from Mojosari, Banyuputih to Sumberanyar. The more northward from this deposit was the coastal deposits, which consist of loose sand, whereas river sediments are found around Banyupait, which consists of free grains of sand, gravel to boulder size.

The Old Ijen volcanic pyroclastic breccia unit consists of pyroclastic flow breccias and pyroclastic fall breccias. Pyroclastic flow breccia deposits (Figure 5) have thicknesses varying between 20-75 cm, and up to more than $1 \mathrm{~m}$, these pyroclastic deposits were revealed well in Bantal Village. Deposition pyroclastic breccia flow shows the layering structure and unsorted texture with moderate sand-gravel size. Angularshaped fragments are consisting of scoria and pumice basalt embedded in a sand-sized volcanic material matrix. Petrographically, this pyroclastic flow breccia was composed of angular shaped fragments consisting of basalt scoria, plagioclase, quartz, and pumice embedded in a matrix of fine volcanic material (Figure 6). While pyroclastic fall breccias with thicknesses vary between 20-50 cm exposed in Banger Village. The pyroclastic fall breccia deposits (Figure 7) show graded bedding structure and sized medium sand-gravel. The subrounded fragments consisting of basalt (bomb, scoria) and pumice in the volcanic matrix of sand size.
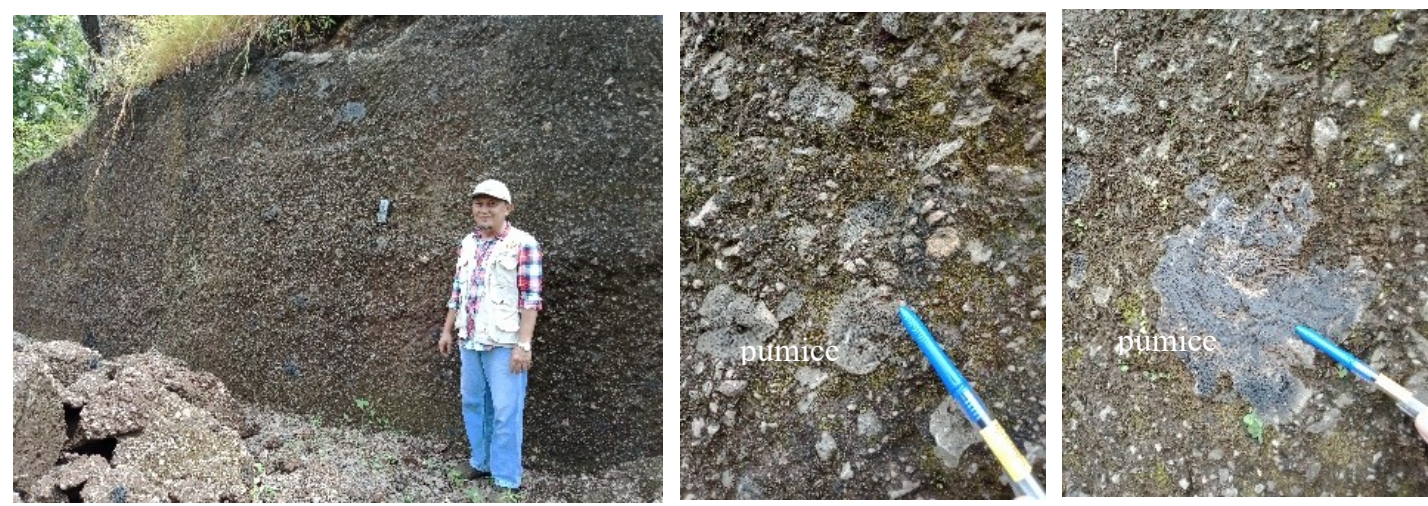

Figure 5. Shows the deposits of pyroclastic flow breccia of the Old Ijen Volcano in the Bantal Village, fragments consist of basalt scoria and pumice.
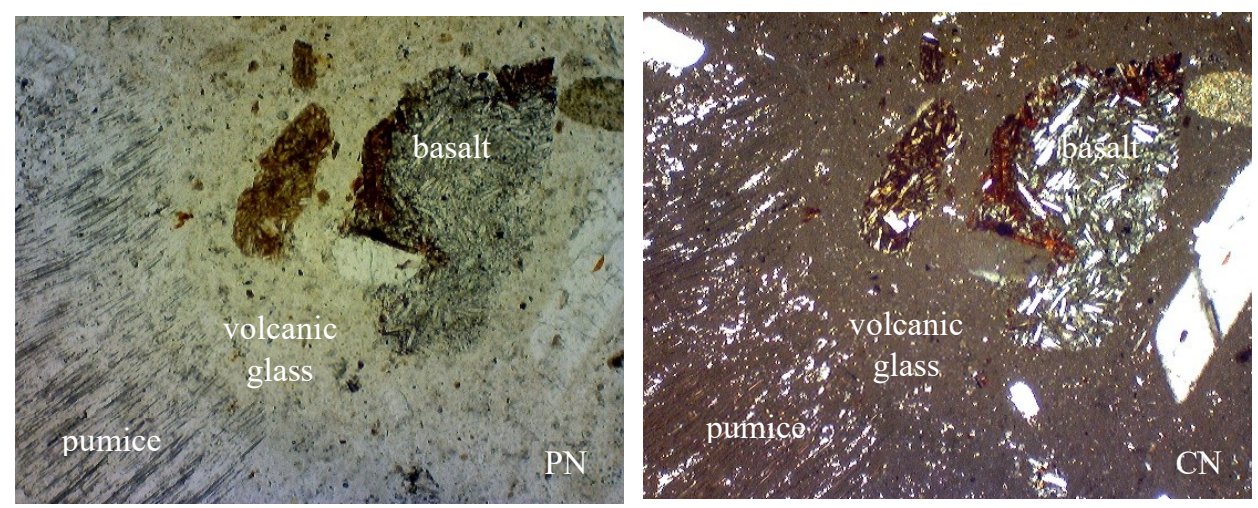

Figure 6. A thin section of the petrographic of a pyroclastic flow breccia shows the presence of pumice and basalt fragments in a volcanic glass matrix. Basalt fragment shows the flowing texture of microlite plagioclase. PN: Parallel Nicol, CN: Cross Nicol. 

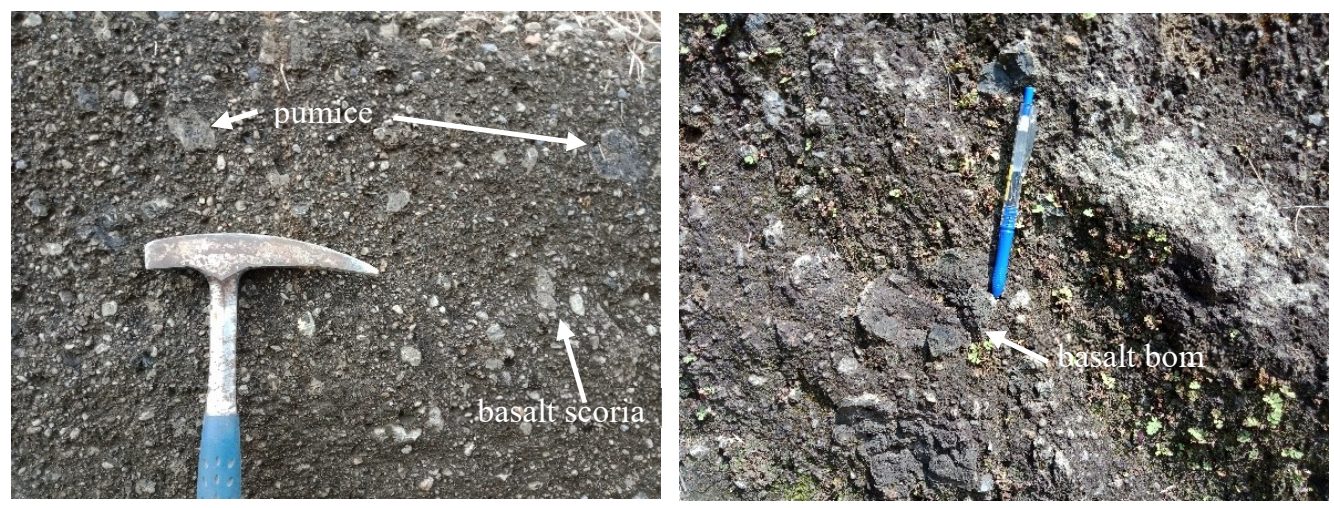

Figure 7. Showing the pyroclastic fall breccia deposits with fragments consist of basalt (bomb, scoria) and pumice. Fragments with gravel sizes were subrounded in smaller volcanic material matrixes (sandgravel).

The lahar breccia Bogor exposed at Mojosari, showing the bedding structure and the size of mediumgravel sand (Figure 8). Medium rounded fragments consisting of basalt scoria and a few pumice, these fragments embedded in sand-sized of the volcanic matrix. Petrographically, lahar breccia (Figure 9) was composed of angular shaped fragments consisting of basalt scoria fragment, lithic (pumice breccia), plagioclase, pyroxene, quartz and hematite embedded in a matrix of the fine volcanic material. The hematite is formed due to rocks interacting with the acidic water of the Banyupait River (location at Sukorejo). This lahar breccia deposit is found in the area showing flat morphology and rocks appearing more compact compared to pyroclastic flow and fall deposits.

The alluvial river unit was composed of loose sand-boulder sized material that is spread on the riverside, especially in the Banyupait River flow (Figure 10). The fragment consists of basalt, andesite, pumice, and boulder breccia with a rounded shape. Bedding and cross-bedding sediment structures were found generally in these deposits. At the base of the Banyupait River, rocks undergo oxidation due to the process of acidic water river interaction with rocks. This phenomenon results in reddish-colored rocks and petrographic observations showing that pyroxene and plagioclase from basalt are replaced into hematite and chalcedony (Figure 24), whereas coastal deposits are coarse-sized sand deposits scattered on the coast. The sediment deposits were the result of the collapse of rocks in the upper of the Banyupait River from Mount Ijen and then transported by this river and deposited to the coast.
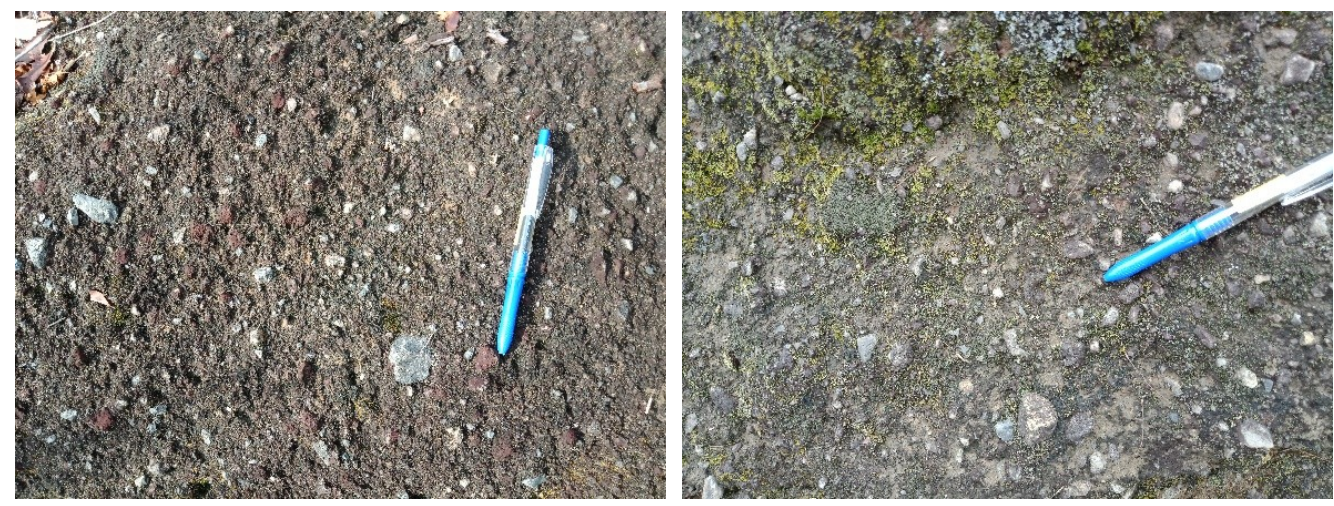

Figure 8. Outcrops of lahar breccia show unsorted texture and subrounded basalt scoria fragments. 

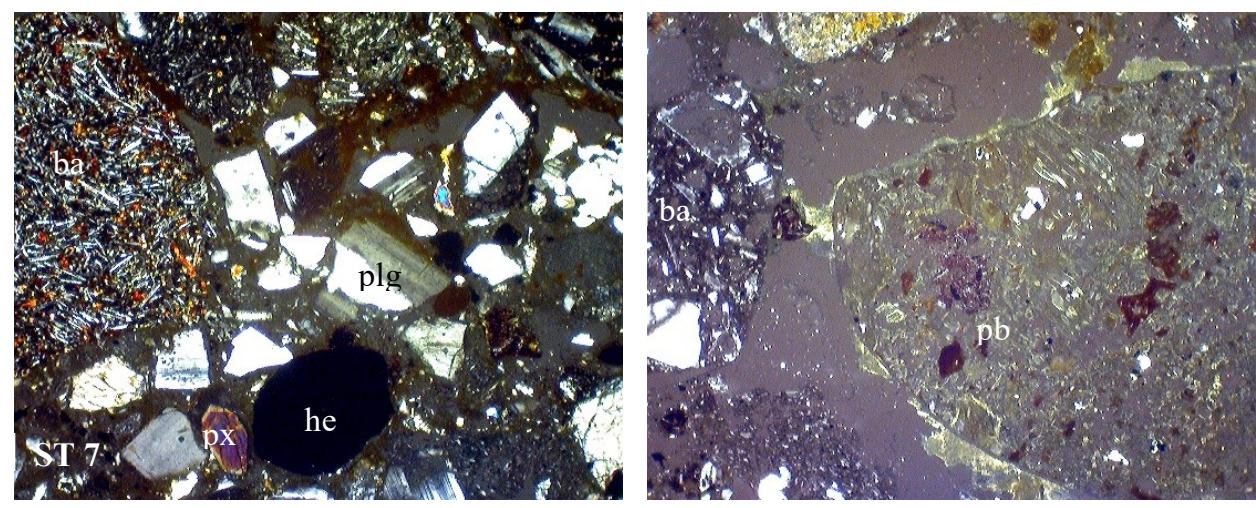

Figure 9. Shows micrograph of basalt (ba) fragments, lithic (pumice breccia: pb), plagioclase (plg), pyroxene (px), and hematite (he) from the lahar breccia unit of Bogor Formation. Hematite is formed due to rocks interacting with the acidic water of the Banyupait River (location at Sukorejo).
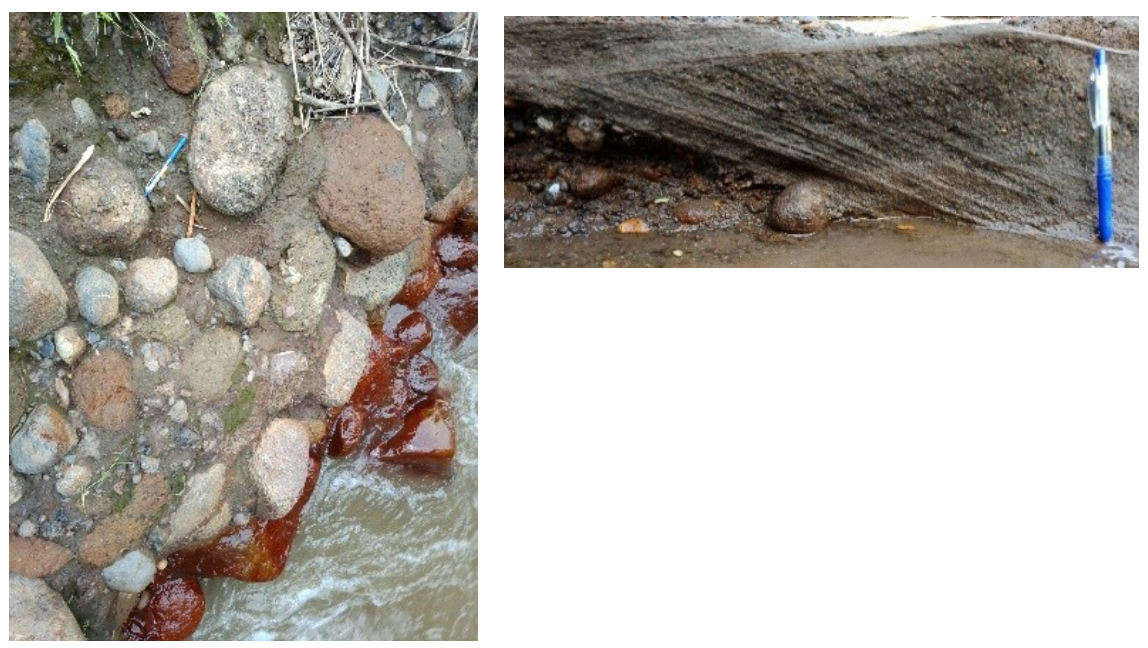

Figure10. Alluvial deposits in Banyupait River at Bantal Village. In the river, bedrocks show a reddish color indicating the interaction of acidic water and rocks, the planar cross-bedding structure as the identifier of alluvial deposits. 


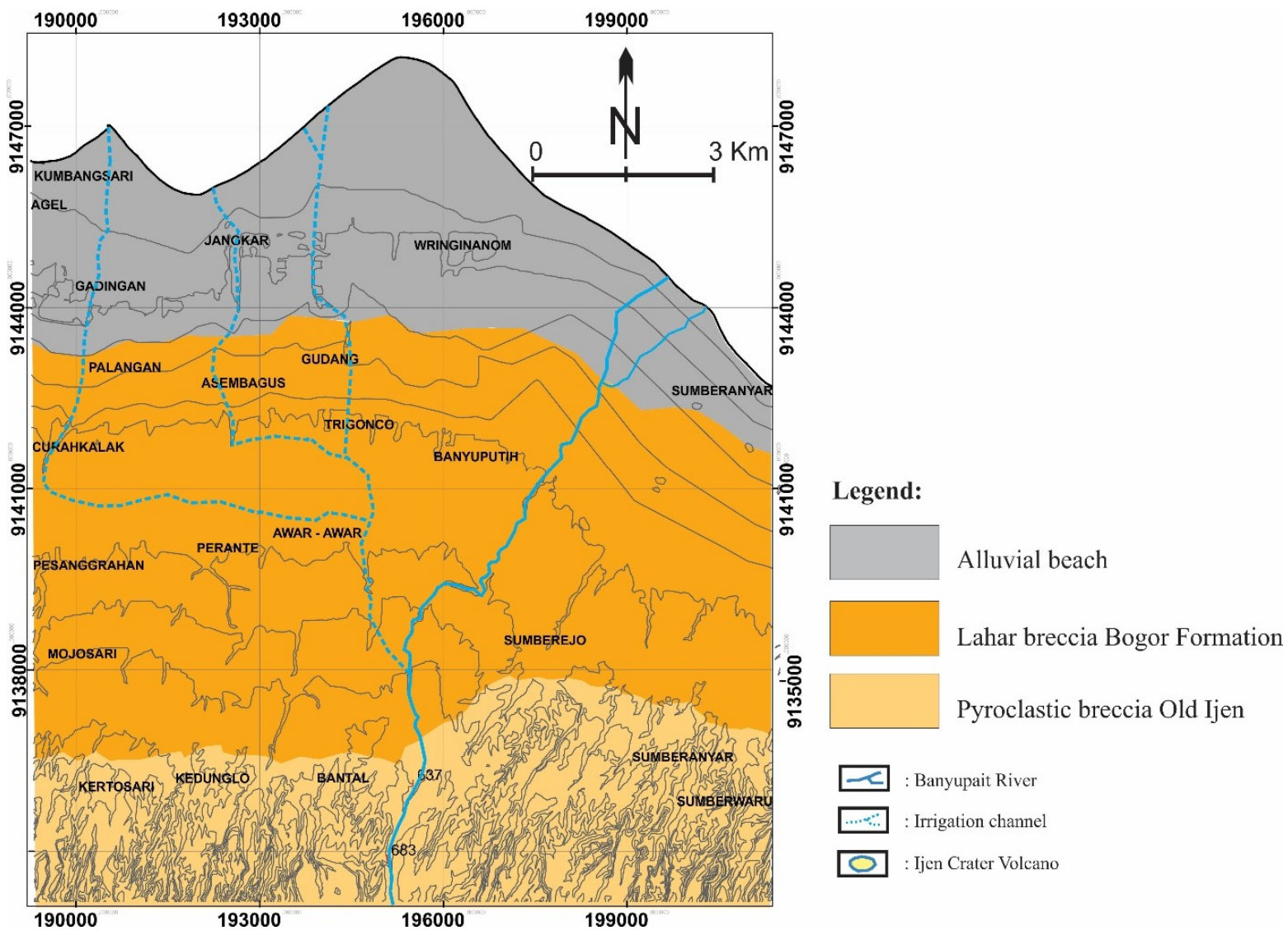

Figure 11. Geological map of the study area.

\subsection{Water geochemistry}

The ICC was one of 63 volcanoes in Indonesia that have a crater. [2, 11, 12] explain that Ijen crater lake emits hot magmatic gas coming out from under the crater lake with acidic $\mathrm{pH}(\mathrm{pH}<1)$, and it was the most significant natural acid lake in the world [5]. The value of lake $\mathrm{pH}$ for the past 50 years was consistently low $(\mathrm{pH}=0-0.4)$ and produced large amounts of native sulfur [3]. [1,4] explain that in the Ijen Crater Lake at depths of up to $100 \mathrm{~m}$, the composition and chemical concentration of lake water is relatively homogeneous. [12] the acidic lake leaked under the surface so that the crater water entered the river, the river water became acidic. This very acidic Ijen Crater water has a concentration of nearly 500,000 tons of dissolved metal, including 200,000 tons of aluminum and 1,000 tons of titanium [36]. Then [2] explained that the Ijen volcanic crater contained very high concentrations of $\mathrm{Cl}, \mathrm{S}$, and $\mathrm{F}$, the maximum concentration of $\mathrm{Cl}=25,000 \mathrm{ppm}, \mathrm{S}$ total $=25,000 \mathrm{ppm}$, and $\mathrm{F}=1300 \mathrm{ppm}$.

Crater lake water also contains total dissolved solids (TDS), an average of $102 \mathrm{ppm}$. Fluctuations in the chemical concentration of crater water are strongly influenced by the season, so the supply of magmatic chemical elements from fumarole/solfatara into the crater lake can be influenced by fluctuations in rainfall [2]. The chemical composition of condensate solfatara Ijen Crater was very dangerous, because it contains $\mathrm{NH}_{3}=2,789.19 \mathrm{ppm}, \mathrm{SO}_{4}=24,259.86 \mathrm{ppm}$ and $\mathrm{Cl}=33,389.26 \mathrm{ppm}, \mathrm{Ca}=44.30 \mathrm{ppm}, \mathrm{Al}=36.24 \mathrm{ppm}$, $\mathrm{SiO}_{2}=22,65 \mathrm{ppm}, \mathrm{Fe}=33.68 \mathrm{ppm}, \mathrm{Mg}=9.20 \mathrm{ppm}, \mathrm{Na}=4.08 \mathrm{ppm}$ and $\mathrm{Mn}=0.56 \mathrm{ppm}$ [37]. [16] explained that springs in the Banyupait River formed needles and gypsum blades, which precipitated during evaporation, forming a fine layer of gypsum cascade on the rocks. The rocks exposed in the valley walls 
consist of pyroclastic layer, lava flow, lahar, ash, and mud deposits. Consolidated lava deposits were common in the downstream, and these rocks also are seen at the bottom of the Banyupait River.

The Banyupait River is upstream in the Ijen Crater. In the Bantal area, the Banyupait River flow is divided into two lanes; namely, the east path is the Banyupait river flow that flows directly to the sea (the Madura Strait), while the west path is an irrigation channel built by the government to used as irrigation of agricultural land. Agriculture in the study area is predominantly inhabited by planting sugar cane because, in the Asembagus area, there is also a sugar cane factory-built since the Dutch era. This research was carried out water sampling in the eastern Banyupait River flow and irrigation in the western Banyupait River. Water samples are taken from streams, irrigation, and wells, then $\mathrm{pH}$ measurements and water chemical analysis are carried out.

\subsection{1. $\quad$ HH and chemical composition of the Banyupait river}

The Ijen Crater dam was built during the Dutch era after it is discovered that the first eruption of Ijen had formed a crater and filled with rainwater mixed with eruption material, which contained a lot of sulfur (sulfur). The condition of the dam was currently experiencing a leak on the side and top so that the crater water flows directly following the Banyupait River flow. The river water coming out of the Ijen Crater dam has a $\mathrm{pH}$ between $0.35-0.89$. The condition of the water was yellow, bubbly, smells of sulfur, the steam when it smells was very stinging so that chemical reactions can occur to the rocks and soil around the river. In the Belawan region, hot water has a water $\mathrm{pH}$ between 2.5 and 4.0. It was due to a mixture of water between the Banyupait, Ampar, and Kaligedang River. The watercolor shows cloudy, slightly foamy colors and low viscosity. The influence of other river water that enters the Banyupait River flow, makes the $\mathrm{pH}$ of the water slightly rise and the physical condition of the water changes. [1] the Banyupahit River water has a $\mathrm{pH}$ of $0.19-3.62$, which flows along $3 \mathrm{~km}$ from the active crater. [38] explains that the $\mathrm{pH}$ of water along the Banyuputih River does not change until in residential areas, rice fields, and sugar cane plantations. The results of laboratory analysis show that in the Banyupait River water, it shows the element content of fluoride (F) of 1.31 - $2.04 \mathrm{ppm}$; sulfate content $\left(\mathrm{SO}_{4}\right)$ of 309.2 - $30.889 \mathrm{ppm}$ and chloride $(\mathrm{Cl}) 8.69$ $3,928.43 \mathrm{ppm}$. The results of the sample water analysis from the population well, i.e., from shallow wells (depth $<10 \mathrm{~m}$ ), the $\mathrm{pH}$ was $6.35-7.50$; fluoride content $(\mathrm{F})$ of $0.15-1.42 \mathrm{ppm}$; in borehole wells with fluoride $(\mathrm{F})$ content of 1.55 - $1.93 \mathrm{ppm}$; sulfate $\left(\mathrm{SO}_{4}\right)$ content of $32.79-34.7 \mathrm{ppm}$ and chloride $(\mathrm{Cl})$ content of $2.47-12.45$ ppm. Whereas in the Lewung and Samir Villages were the top locations of the Bantal Village, the river water was used by the community for bathing and washing. Also, it is used to irrigate rice fields for corn and sugarcane plants using waterwheels assembled by local communities. Pet cow and buffalo also use the Banyuputih River for bathing and drinking. Whereas in the Sempol river, which is the right branch of the Banyupahit River, shows an obvious hue. Residents use the springs for drinking water, and the $\mathrm{pH}$ of the water is around $7.15-8.01$. Kucing River was the left branch of the Banyuputih River, showing clear water hues, odorless, and used by residents as a source of drinking water.

\subsection{1. $\mathrm{pH}$ and $\mathrm{SO}_{4}$ measurements}

The $\mathrm{pH}$ measurement of Ijen Crater Lake was consistently low, and it was between $\mathrm{pH}=0-0.4$ [3]. The research area was the northern slope of the Ijen volcano, which was passed by the Banyupait River. In this area, $\mathrm{pH}$ measurements were carried out on 23 locations along with the Banyupait River flow from Bantal Village to downstream, and $\mathrm{pH}$ measurements of wells were carried out on 24 sites. The $\mathrm{pH}$ measurement of the Banyupait River is divided into two parts, i.e., the western Banyupait River and the eastern Banyupait River. The east part of the Banyupait River was a direct river flow from the Ijen Crater Dam, while the west part of the Banyupait River was a river whose water is used for rice field irrigation. This river flow to the downstream direction was regulated by residents with an open and close door of the dam system and mixed with artesian well water, so that river water was not too acidic and can be used for agricultural irrigation. The $\mathrm{pH}$ of the western part of the Banyupait River ranges from 3.3-7.4, while in the eastern region, the $\mathrm{pH}$ is $2.7-7.1$. The $\mathrm{pH}$ of the water wells water around the western and eastern parts of 
Banyupait River was relatively similar between 5.8-7.2 (Figure 12). In general, both the $\mathrm{pH}$ of river water and shallow wells further towards the sea indicate a higher $\mathrm{pH}$ or towards a neutral $\mathrm{pH}$. If a flow chart is made that starts from the upstream of Bantal Village, the $\mathrm{pH}$ of the Banyupait River water is around 2.77.1 (Figure 13) and the $\mathrm{pH}$ of shallow well water around 5.8-7.2 (Figure14).

The $\mathrm{SO}_{4}$ content in Ijen Crater, according to Wittiri and Sumarti (2000) in [38], is around 24,259.86 ppm, while $\mathrm{SO}_{4}$ in the study area is around 220-683 ppm (Figure 15 and 16). From the distribution of $\mathrm{SO}_{4}$ content, it shows that $\mathrm{SO}_{4}$ concentration from the Ijen crater towards the river mouth has decreased.

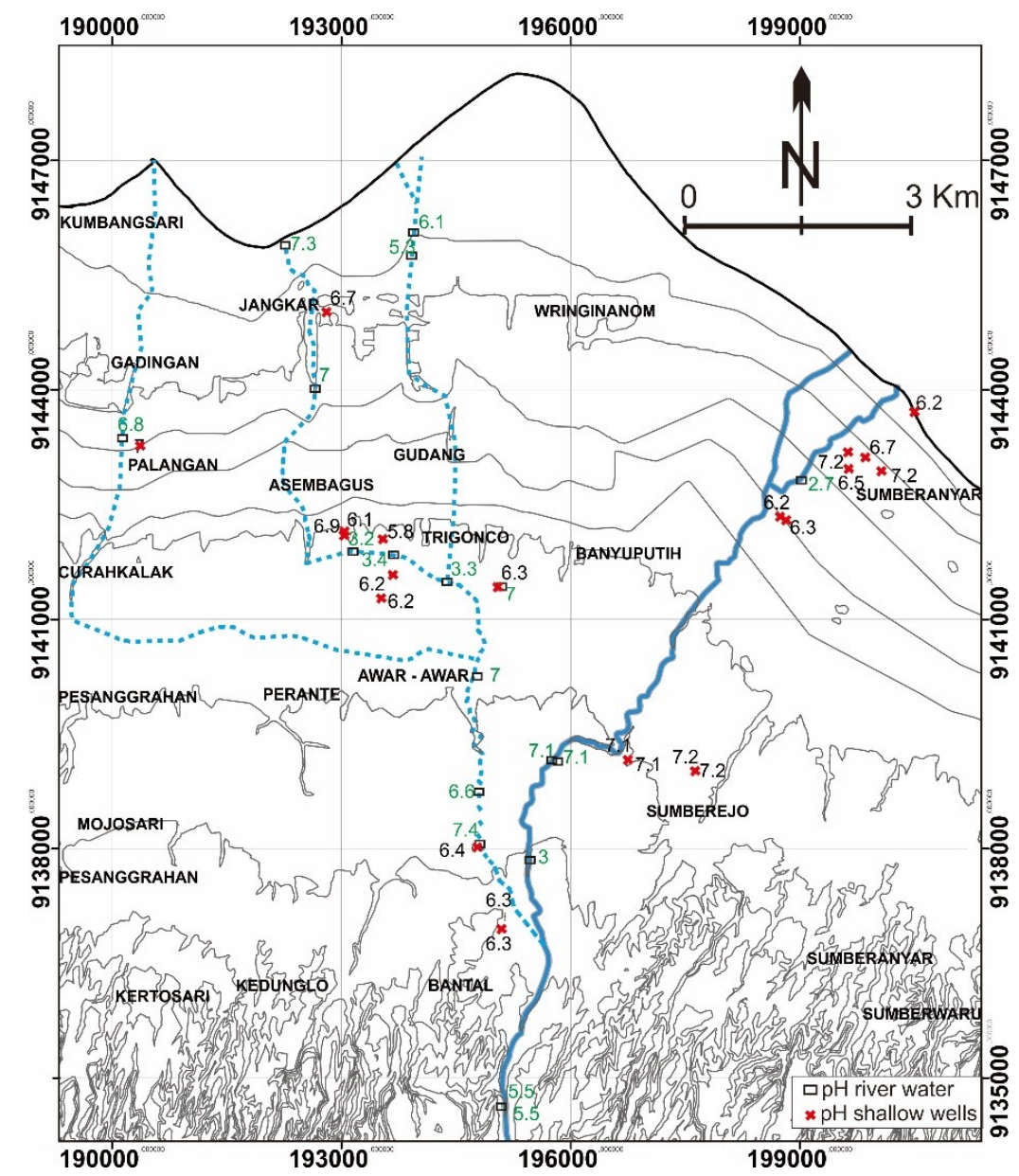

Figure 12. Distribution of $\mathrm{pH}$ measurements of water samples. 


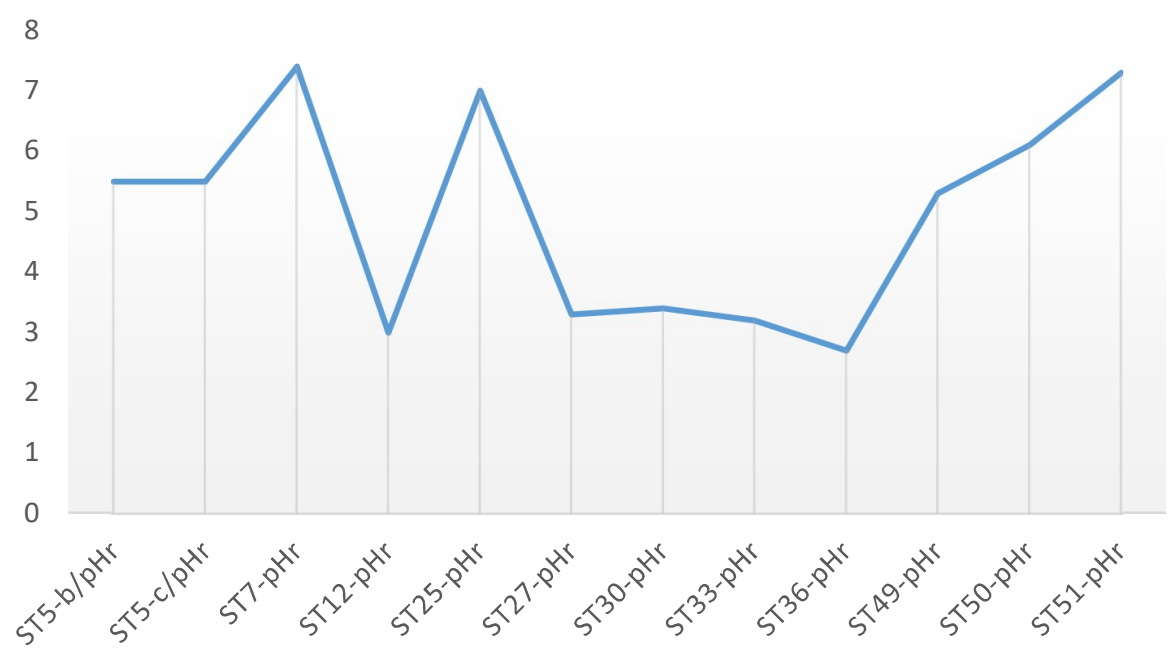

Figure 13. Distribution of $\mathrm{pH}$ water samples of Banyupait River.

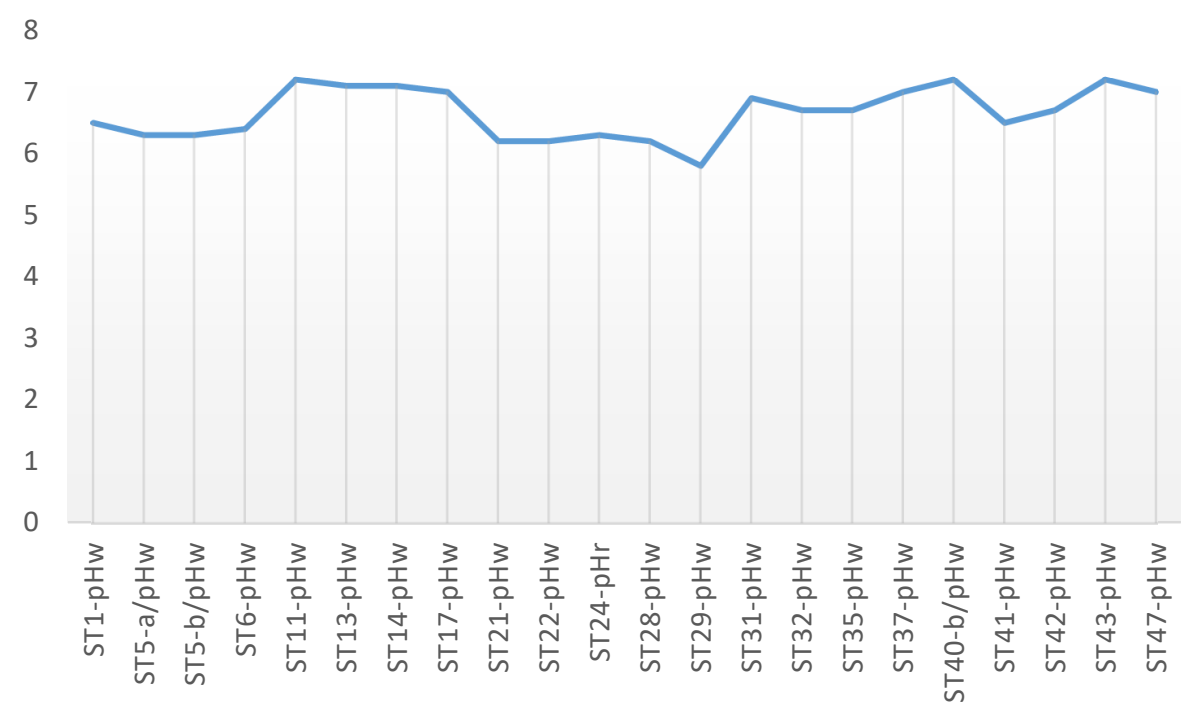

Figure 14. Distribution of $\mathrm{pH}$ water samples from shallow wells. 


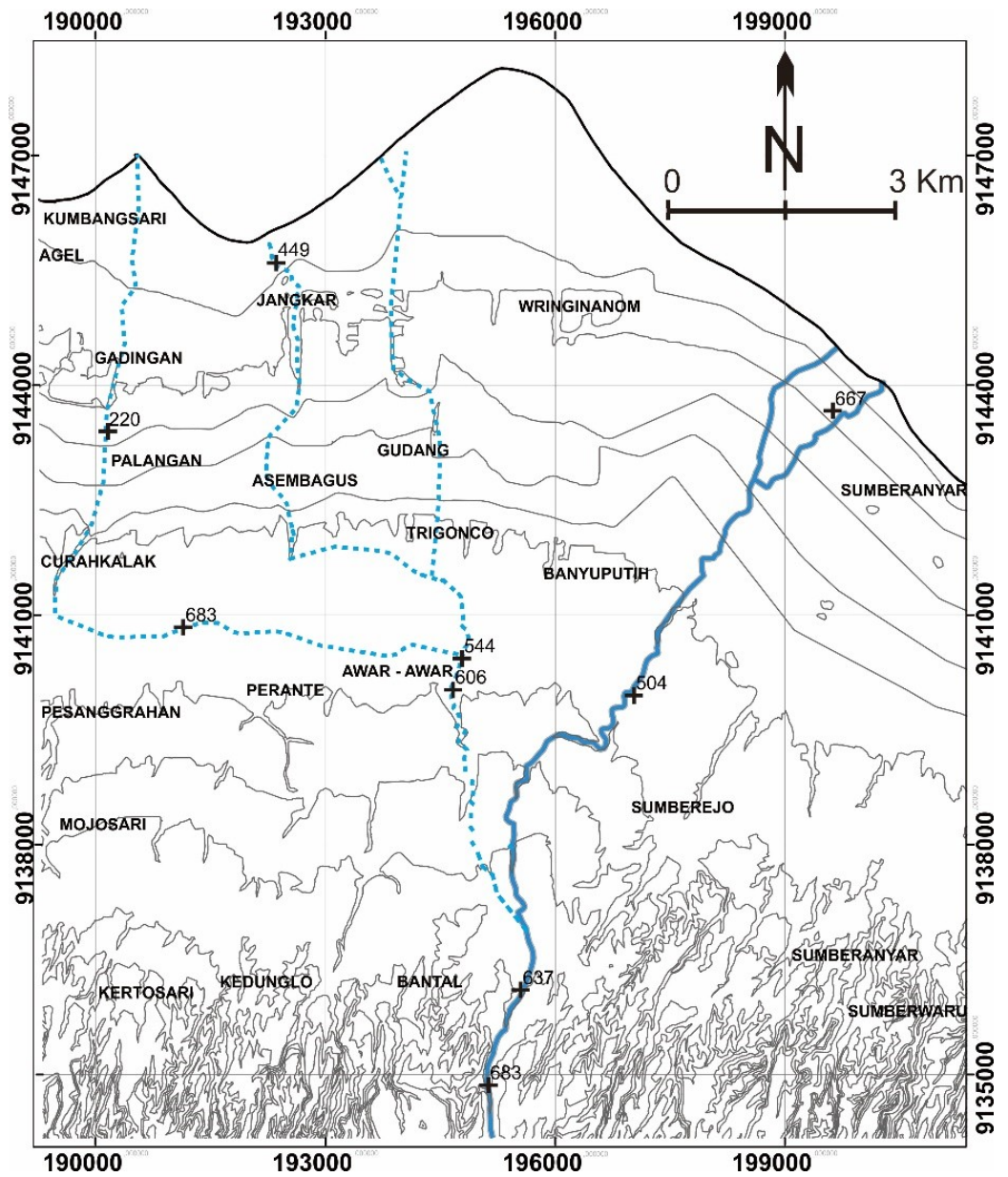

Figure 15. Distribution of $\mathrm{SO}_{4}$ measurements of water samples (+: $\mathrm{SO}_{4}$ concentration in $\left.\mathrm{ppm}\right)$.

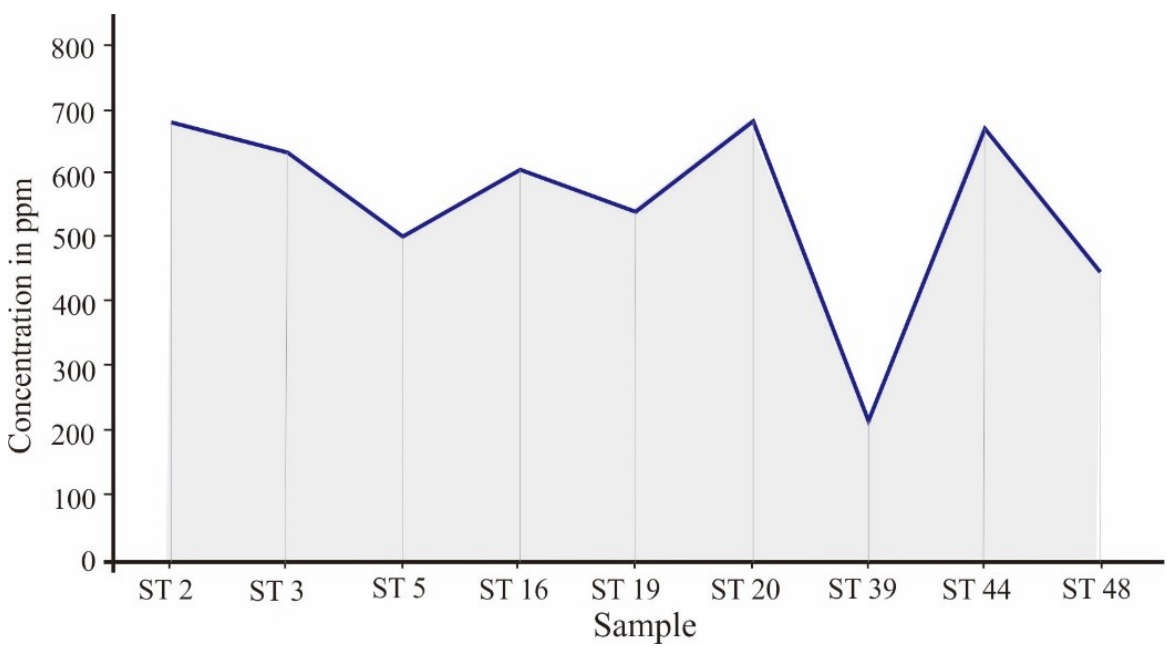

Figure 16. Distribution of $\mathrm{SO}_{4}$ measurements of water samples (in ppm). 


\subsubsection{Water Chemistry}

\subsubsection{Cation and Anion}

The chemical composition of the solfatara condensate Ijen Crater contains $\mathrm{Cl}=33,389.26 \mathrm{ppm}, \mathrm{Ca}=44.30$ ppm, $\mathrm{Mg}=9.20 \mathrm{ppm}, \mathrm{Na}=4.08 \mathrm{ppm}$ and $\mathrm{Mn}=0.56 \mathrm{ppm}$ (Wittiri and Sumarti, 2000 in [38]. While analysis of cation anions $\left(\mathrm{Na}^{+}, \mathrm{K}^{+}, \mathrm{Ca}^{2+}, \mathrm{Mg}^{2-}\right.$ and $\left.\mathrm{Cl}^{-}\right)$conducted on eight water samples in the Banyupait River flow of the study area which is the northern slope of Mount Ijen shows that the concentration of the cationanion elements is $\mathrm{Na}^{+}$(10.743-260.558 ppm), $\mathrm{K}^{+}$(6.331- 28.451 ppm), $\mathrm{Ca}^{2+}$ (9.181-79.093 ppm), $\mathrm{Mg}^{2+}$ $(6.313-43.835 \mathrm{ppm})$ and $\mathrm{Cl}-(2.350-434.61 \mathrm{ppm})$ see Table 1 . These elements have a tendency towards the river estuary the concentration of cations and anions has increased especially the $\mathrm{Cl}^{-}$anion, but when compared to the concentration of the Ijen crater cation-anion elements, the Banyupait River water cationanion element showed an increase, except the $\mathrm{Cl}^{-}$element which decreased (Figure17 and Figure 18).

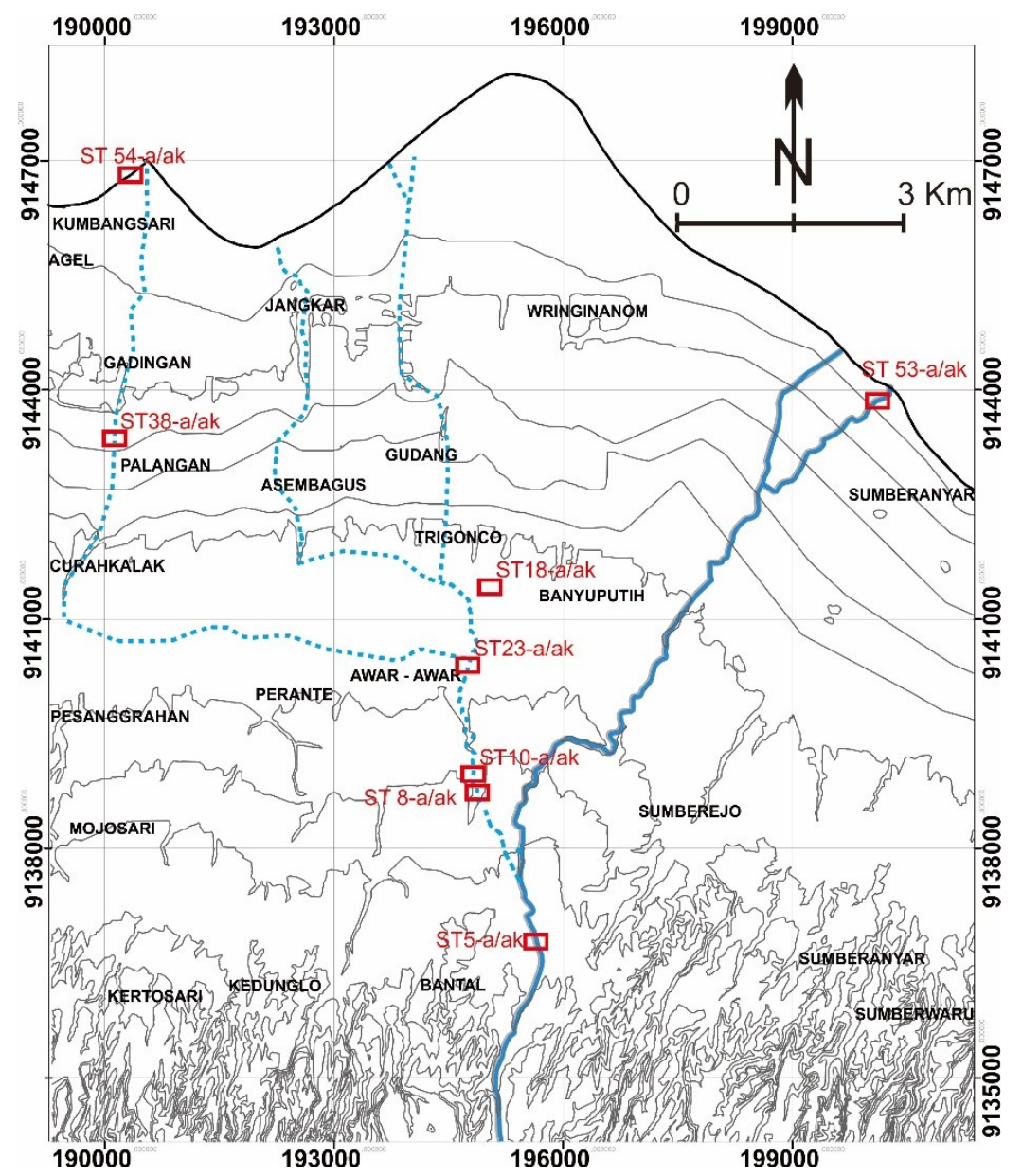

Figure 17. Location cation-anion of water chemistry samples at the research area. 
Table 1. Analysis of cation, anion at the Banyupait River water, and river estuary and coastal well.

\begin{tabular}{lccccc}
\hline \multirow{2}{*}{$\begin{array}{c}\text { No. } \\
\text { Samples }\end{array}$} & \multicolumn{3}{c}{ Cation (ppm) } & & $\begin{array}{c}\text { Anion } \\
\text { (ppm) }\end{array}$ \\
\cline { 2 - 6 } & Na & K & Ca & Mg & Cl \\
\hline Banyupait River water & & & & \\
ST5-a/ak & 14.713 & 7.522 & 10.474 & 8.726 & 3.66 \\
ST8-a/ak & 47.631 & 17.037 & 62.246 & 46.934 & 2.35 \\
ST10-a/ak & 50.941 & 21.123 & 52.123 & 43.555 & 15.10 \\
ST53-a/ak & 51.007 & 23.576 & 57.501 & 43.835 & 434.61 \\
\multicolumn{7}{l}{} & & & & \\
River and river estuary water & & & \\
ST18-a/ak & 10.743 & 6.331 & 9.181 & 6.313 & 146.20 \\
ST23-a/ak & 6.385 & 7.339 & 5.727 & 3.559 & 104.54 \\
ST38-a/ak & 260.558 & 28.451 & 79.093 & 71.726 & 168.95 \\
\multicolumn{7}{l}{ Coastal well } & & & & & \\
ST54-a/ak & 47.869 & 19.448 & 48.924 & 40.962 & 157.31 \\
\hline
\end{tabular}

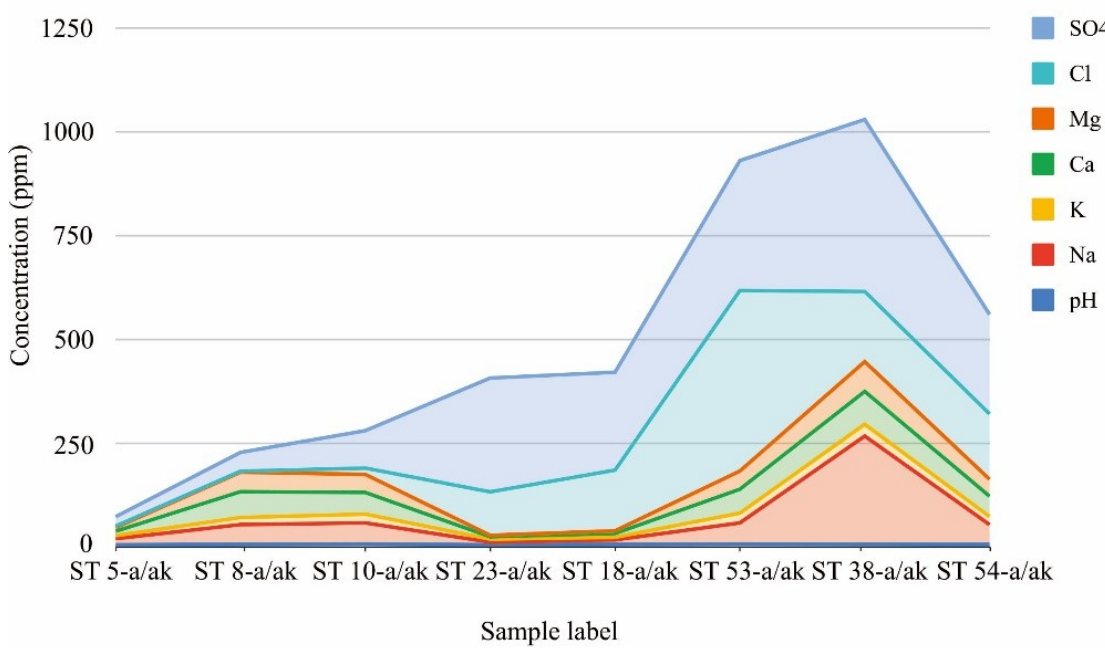

Figure 18. Diagram of the anion-cation element (in ppm) of water chemistry samples at the research area.

\subsubsection{Water isotope}

The chemical history of the origin of water can be traced by measuring the ratio of isotope abundance at the time of the present phase together [39]. So the analysis of $\delta^{18} \mathrm{O}$ and $\delta \mathrm{D}$ can be used to identify meteoric water isotopes in certain regions so that they can be used to study the evolution of surface and subsurface water. The analysis is usually displayed on plots of two isotopes, such as Table 2 and Figure 19. Meteoric water plotted lies along a straight line in the equation $\delta \mathrm{D}=8 \delta^{18} \mathrm{O}+10[40,41]$. [3] explain that lake water isotopes show strong shifts of ${ }^{18} \mathrm{O}$ and $\mathrm{D}$ isotopes due in large part to the kinetic isotope effects associated with evaporation at high lake water temperatures. They are coupled with the possible contribution of heavy magmatic isotopes that are condensed at depth. Water-rock interactions in the subsurface hydrothermal 
system can also affect the final value of the ${ }^{18} \mathrm{O}$ isotope from lake water. In the study area, ${ }^{18} \mathrm{O}$ and $\mathrm{D}$ isotopes are compared with the results of an analysis of ${ }^{18} \mathrm{O}$ and $\mathrm{D}$ isotopes in the Ijen crater lake conducted by [3]. Plotting results of $\delta^{18} \mathrm{O}$ and $\mathrm{D}$ in the study area which included samples of river water and wells are compared to the water craters of Ijen from [3] showed that river water and well water in the study area included meteoric water (Figure 20), while the Ijen Crater which was upstream of the Banyupait River was water mixed with magmatic fluids.

Table 2. Analysis of $\delta^{18} \mathrm{O}$ and $\mathrm{D}$ of Ijen Crater Lake water [3], Banyupait River water, and river estuary and coastal well.

\begin{tabular}{|c|c|c|}
\hline $\begin{array}{c}\text { No. } \\
\text { Samples }\end{array}$ & $\begin{array}{c}\delta^{18} \mathrm{O} \\
(\%)\end{array}$ & $\begin{array}{c}D \\
(\%)\end{array}$ \\
\hline \multicolumn{3}{|c|}{ Ijen Crater Lake water [3] } \\
\hline IJP96-3 & 8.7 & 0.6 \\
\hline IJP96-4 & 8.7 & -0.7 \\
\hline IJP93-5 & 8.8 & 0.9 \\
\hline IJI96-6 & 8.3 & -3.1 \\
\hline CS-85 & 8.3 & -9.4 \\
\hline \multicolumn{3}{|c|}{ Banyupait River water } \\
\hline ST5-b/i & -5.07 & -25.5 \\
\hline ST8-b/i & -6.85 & -9.1 \\
\hline ST10-b/i & -5.14 & $-27,0$ \\
\hline \multicolumn{3}{|c|}{ River and river estuary water } \\
\hline ST18-c/i & -7.62 & $-46,0$ \\
\hline ST24-b/i & -6.43 & -37.2 \\
\hline ST30-b/i & -6.01 & -36.4 \\
\hline ST38-c/i & -7.68 & -46.6 \\
\hline ST54-d/i & -7.34 & -44.3 \\
\hline \multicolumn{3}{|c|}{ Coastal well } \\
\hline ST53-d/i & -7.59 & -45.6 \\
\hline
\end{tabular}




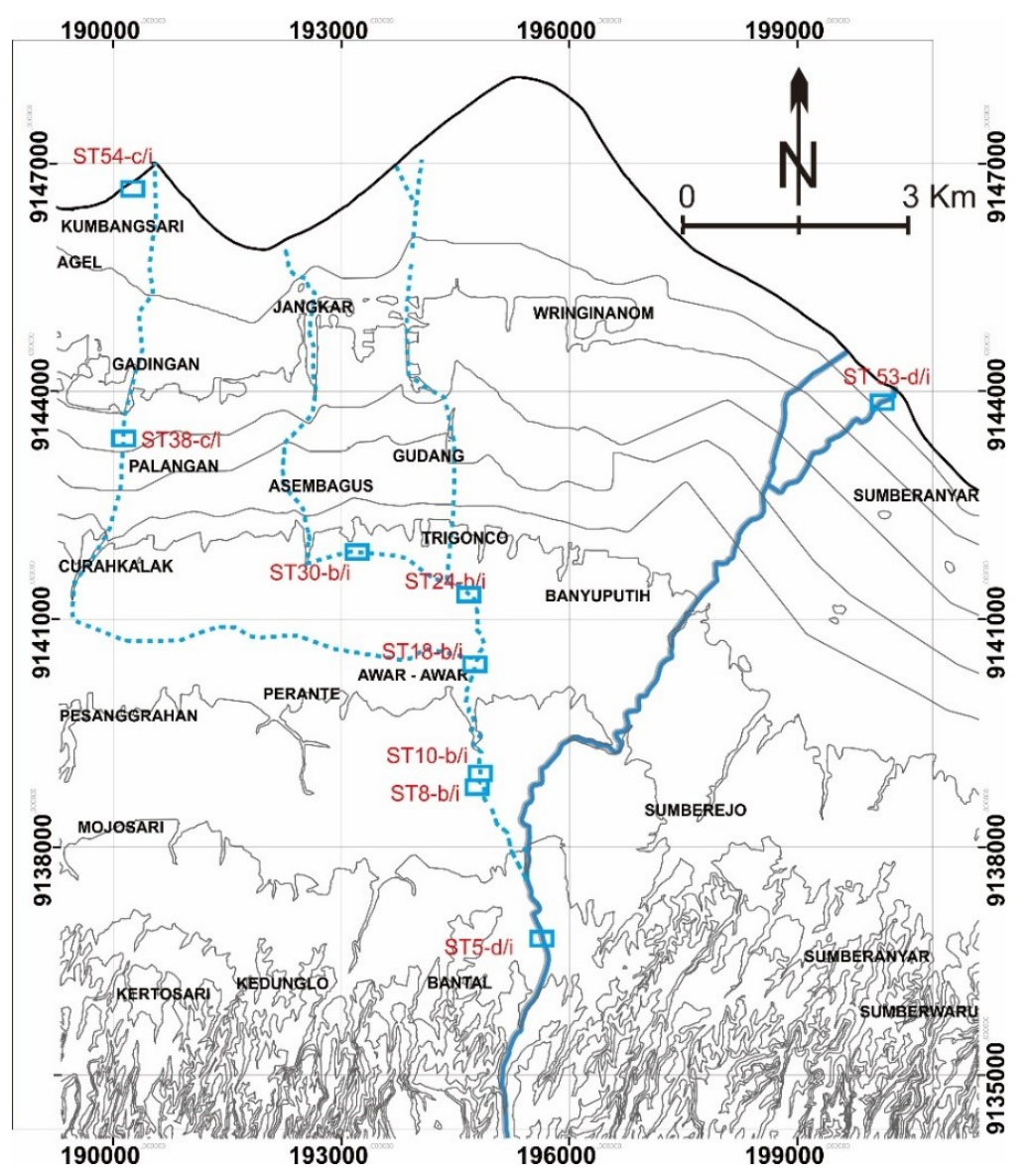

Figure 19. Distribution sample of ${ }^{18} \mathrm{O}$ and $\mathrm{D}$ isotopes from the research area.

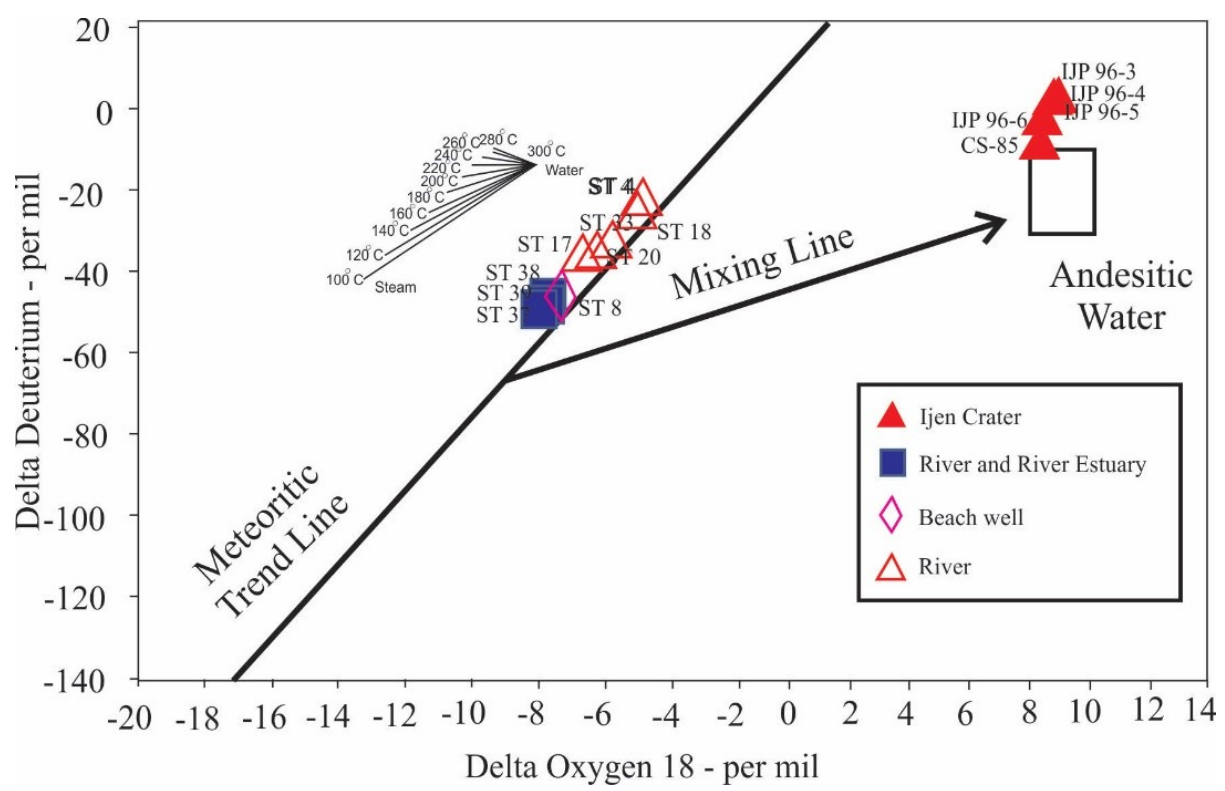

Figure 20. Distribution of ${ }^{18} \mathrm{O}$ and $\mathrm{D}$ isotopes from the research area and Ijen Crater Lake water. Data on $\mathrm{D}$ and ${ }^{18} \mathrm{O}$ isotopes of Ijen Crater Lake water used data from [3]. 


\subsubsection{Rare Earth Element (REE) water}

The rare earth element (REE) geochemistry in acid surface water has been studied by several researchers, such as [42, 43, and 44]. Because different rock types usually have a unique REE profile, REE is often used by geochemists as fingerprints for source areas. [4] explained that REE analytical data in the waters of the active crater lake was minimal. Similarly, in the study area (Figure 21), and REE analysis was carried out to explain the distribution of changes in the concentration of Ijen Crater water to the estuarine river. It is Banyupait acidic river water, which comes from the crater, and as the study area. The negative relationship has occurred between $\mathrm{pH}$ and $\mathrm{Nd}$ concentration from hydrothermal waters, but according to [45] did not find a linear negative relationship between REE and $\mathrm{pH}$ (1.2-4.2) of acidic waters, but illustrates a negative correlation between $\mathrm{pH}$ and $\log [\mathrm{Sm}]$ in the range of $\mathrm{pH} 1,3-8,8$ [46]. As with the distribution pattern of REE of Pinatubo Crater Lake water, REE concentrations are much lower, due to hydrothermal processes and less acidic lake water. It was due to the LREE leaching process, which was faster than the heavy REE (HREE) [47], although the level of REE concentration in water crater lakes was much higher compared to other natural water [4].

In this study, the REE characteristics of the Banyupait River acid water caused by the seepage of the very acidic Ijen Crater water and study the change in concentration from REE to the coastline. A total of 9 water samples from the study area analyzed by REE were obtained from three regions, namely: a). The upstream sector of the Banyupait River, namely in the village of Bantal; b). Banyupait watersheds from the Awar-Awar area to the estuary; c). The coastal area represented by shallow well water d). Spring cold water.

The results of the analysis of these water samples are then plotted on a semi-logarithmic diagram (Figure 22). As for the data of Ijen Crater Lake water (5 samples) using data conducted by [3]. From the results of the plot in the semi-logarithmic spider diagram of the effects of normalization of rare earth elements from the acid water of Ijen Crater Lake conducted by [3] and several samples of the study area (Table 3.) on the increase in atomic numbers, it is generally seen that the crater water, rivers, and well water show a relative pattern of decreasing direction from light rare earth element (LREE) towards heavy rare earth element (HREE), except for the REE pattern of springs. From the results of the plot in the semilogarithmic spider diagram of the results of normalization of rare earth elements from the acid water of Ijen Crater Lake (5 samples) conducted by [3] and several samples of the study area on the increase in atomic numbers, it is generally seen that the crater water, rivers, and well water show a relative pattern of decreasing direction from light rare earth element (LREE) towards heavy rare earth element (HREE), except for the REE pattern of a spring. The concentration value of Ijen Crater LREE shows a value of 2000-4000 times chondrite with a $\mathrm{pH}$ of $0-0.4 \mathrm{in} \mathrm{La}, \mathrm{Ce}, \mathrm{Pr}, \mathrm{Nd}$ and gradually decreases towards heavy rare earth element (HREE) elements up to 800-1000 times chondrite in Dy, Ho, Er, and $\mathrm{Yb}$, while the Tm element has a pattern decreasing up to 100 times chondrite. 


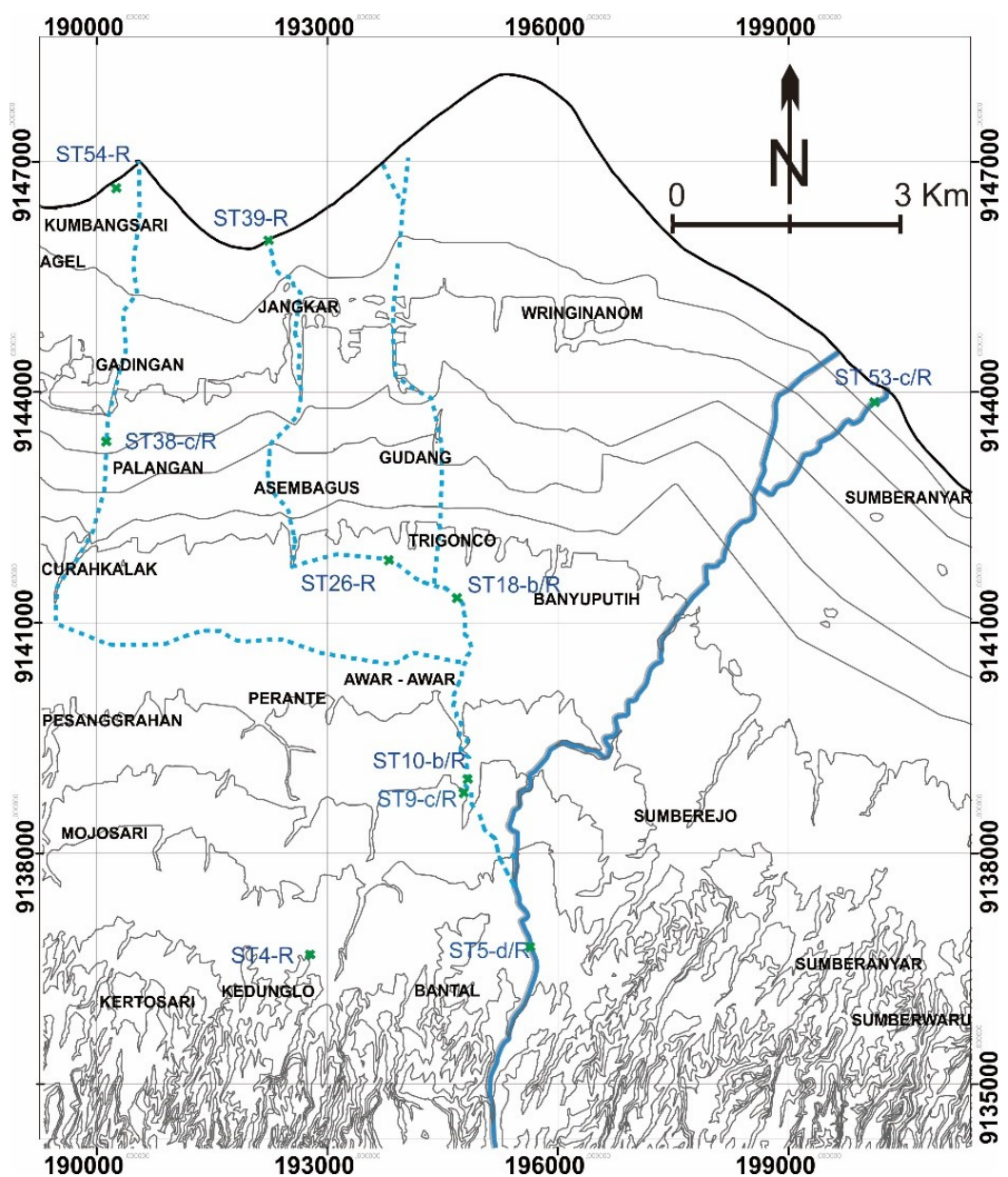

Figure 21. Water sampling map for REE analysis.

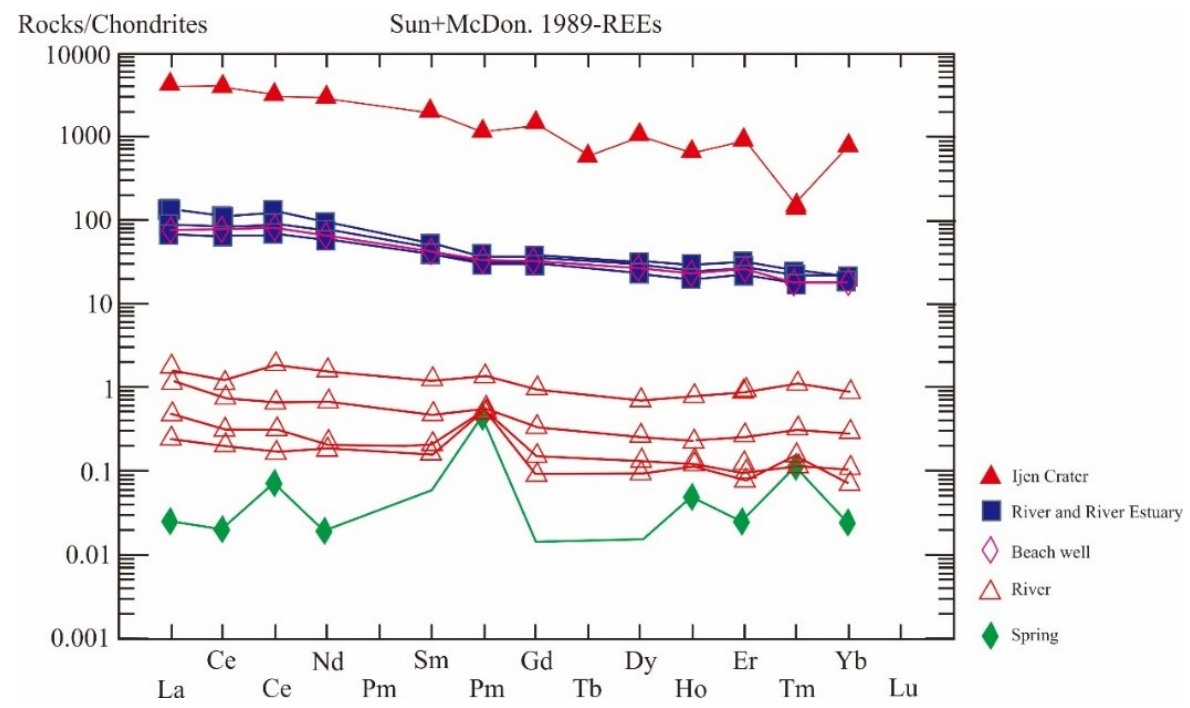

Figure 22. Results of REE analysis of Ijen Crater REE [3], Banyupait River, well water and spring at the research area. 


\section{Discussion}

\subsection{Rock-fluids interaction}

By definition, fluid-rock interaction is the result of a chemical reaction due to the fluid interacting with the rock in its path [1]. Fluid-rock interactions in the Banyupait River occur between Banyupait river water, which has an acidic $\mathrm{pH}$ with the rocks in its path. Fluid through the rock will dissolve aluminosilicate minerals (e.g., feldspar). Dissolution of this mineral is a complex process involving various other chemical reactions; mineral precipitation also occurs, which is relevant to the dissolution feldspar $[48,49,50]$. Chemical reactions take place as follows:

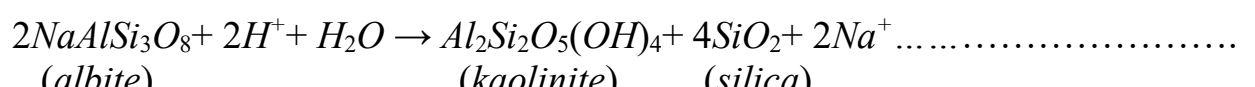

In addition to this, the rocks which are passed by acidic fluid will undergo alteration to argillization, which produces clay minerals such as kaolinite, illite, and montmorillonite [51], iron oxide minerals can also be formed, such as hematite and iron sulfide or pyrite.

Banyupait River water with a $\mathrm{pH}$ of around 2.7-7.2 will react with bedrock that is composed of andesitic or basaltic so that rocks can undergo alteration both physically and chemically. The rocks change color from gray to brownish red. That is due to the interaction of acidic water in the Banyupait River with rocks. Minerals such as plagioclase, pyroxene, and volcanic glass made up of river bedrocks are replaced by chalcedony, clay minerals, and iron oxide/hematite. The change in the color of the bedrock of the Banyupait River can be seen in Figure 23, while the change in the primary mineral constituent rocks into secondary minerals (clay minerals, chalcedony, and hematite) can be seen from petrographic analysis, as in Figure24.
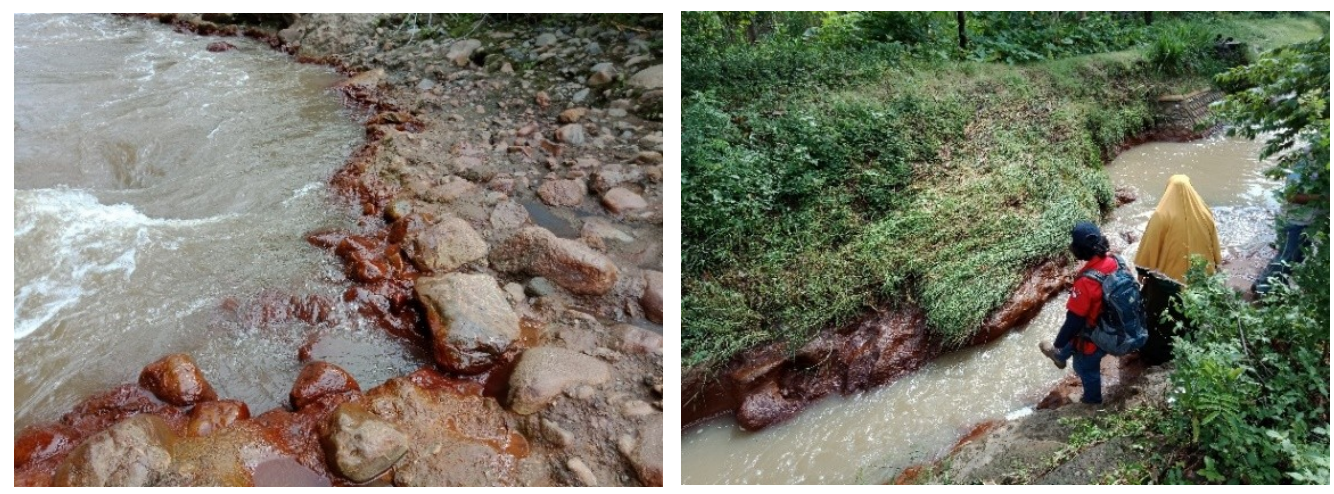

Figure 23. The photo explains that the river bed rocks are brownish due to the rock processes that interact with the Banyupait River acid water.
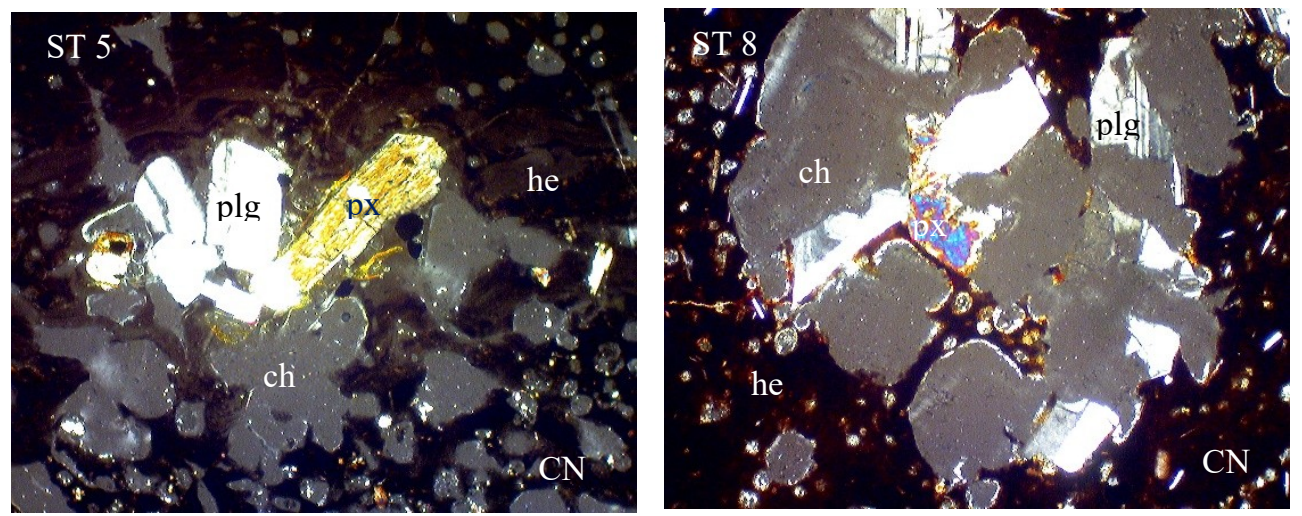

Figure 24. Shows plagioclase minerals (plg), pyroxene (px), and groundmass of volcanic glass altered due to interacting with the acidic water of the Banyupait River (location at Sukorejo dan Bantal). ch: chalcedony, he: hematite. 


\subsection{Dilution Process}

Acidic water lake that occurs in the Ijen crater can have an impact as volcanogenic pollutants that will endanger the health of the community around Mount Ijen. In addition to the very acidic waters of Ijen Crater Lake, this will, of course, be followed by high concentrations of heavy metal and other toxic elements, as is the opinion of [52, 53, 54, and 1]. As is the case in the Ciwide River, that the composition is rich in sulfur and chlorine at a pH between 2.0 and 3.5, it will be followed by high concentrations of heavy metal and other toxic elements [55]. The extreme chloride sulfate acid of lake water produced by Ijen Crater water is caused by the interaction of rising magmatic gas mixed with meteoric water. Due to the high temperature of volcanic gas, it will be able to transport metal and non-metal elements [56], thereby increasing the concentration of heavy metal and other trace elements in acid lakes [57]. Then in the area of Mount Ijen, crater lake seepage water will affect the concentration of surface and groundwater in the area around the Ijen Volcano. It is shown by the influence of the $\mathrm{pH}$ Banyupait River water on the $\mathrm{pH}$ of shallow well water (around 6.2-6.7) around the Banyupait River flow. Besides, during flow to the sea, the $\mathrm{pH}$ of Banyupait River water (2.7-7.4) experienced dilution due to the addition of artesian well water so that the $\mathrm{pH}$ of the Banyupait River water in the downstream is more neutral than in the upstream, and the water can be used to irrigate agricultural land in the form of chilies, tomatoes, rice, and eggplants. Besides that, the results of $\mathrm{SO}_{4}$ analysis of water around the Banyupait River show different variations. In the eastern Banyupait River shows a high concentration, which was around 504-683 ppm, while in the west shows a range between $220-683 \mathrm{ppm}$. In general, $\mathrm{SO}_{4}$ levels in the western part of the Banyupait River were relatively low (220-449 ppm). Correspondingly, the concentrations of the elements $\mathrm{Ca}, \mathrm{K}, \mathrm{Mg}$ in the river flow to the coastal estuary show higher concentrations than those in the Banyupait River flow, as shown in Figure 25. It is due to the addition of elements from agricultural activities.

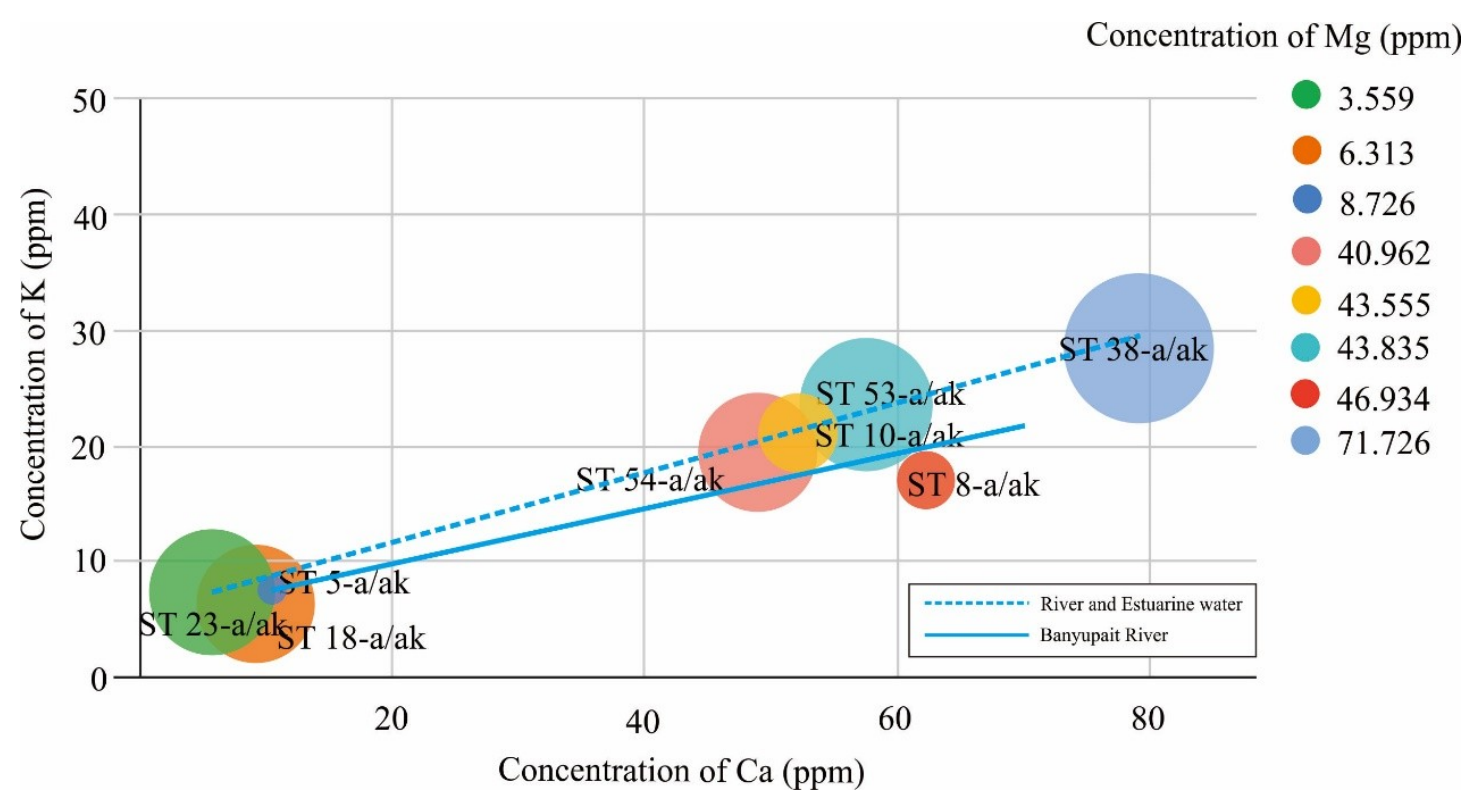

Figure 25. Balloon diagram of the Ca-K-Mg elements which shows that the $\mathrm{Ca}, \mathrm{K}$, and $\mathrm{Mg}$ show a linear pattern.

The $\mathrm{pH}$ condition of the Banyupait River water and $\mathrm{SO}_{4}$ concentration greatly influences the REE element concentration of the Banyupait River acid water. However, the graphic pattern of REE elements in Banyupait River water shows a horizontal pattern, except the zig-zag pattern, is shown by the REE element from the air spring that comes not from the acid water of the Ijen Crater Lake. The horizontal pattern, according to [58] such as the REE profile dissolved from acidic water in the Copahue Crater Lake and the Rio Agrio source originating from the andesitic composition of the Copahue Volcano.

The upstream water of the Banyupait River flows towards the downstream has undergone dilution, because it mixes with springs other than the Banyupait River. It has been demonstrated by the 
distribution of chemical elements REE in Figure 22. This figure also shows the spring water comes from a different source, which is not influenced by Ijen Crater water. Whereas in the water river Banyupait from Awar-Awar until the estuarine river, where river water has been mixed with mixing with artesian well water shows the value of 60-200 times chondrite with $\mathrm{pH}$ of about 6.8-7.3 in the element $\mathrm{La}, \mathrm{Ce}, \mathrm{Pr}, \mathrm{Nd}$ and gradually decreases towards the heavy rare earth element (HREE) up to 20 times chondrite on Dy, Ho, Er, Tm and Yb elements. The Sebulan spring shows a different pattern from the previous type of water, which shows the composition of water with a $\mathrm{pH}$ of about 7 has a value of 0.02-0.08 times chondrite in both LREE and HREE elements, but the concentration increases up to 0.5 times the chondrite in the Eu element. This shows that the spring water comes from a different source; it is not influenced by Ijen Crater water.

In the Banyupait River flow in Bantal Village, the value of the REE concentration of Banyupait River water shows a value of 0.1-2 times chondrite with a $\mathrm{pH}$ of about 3-7 in $\mathrm{La}, \mathrm{Ce}, \mathrm{Pr}, \mathrm{Nd}$, and gradually decreases weakly or relatively flat towards heavy rare earth elements element (HREE) up to 0.08-1 times chondrite on Dy, Ho, Er, Tm and Yb elements. Whereas in the mouth of the river, where river water has been mixed with mixing with artesian well water shows a value of 60-200 times chondrite with a $\mathrm{pH}$ of about 6.8-7.3 in the element $\mathrm{La}, \mathrm{Ce}, \mathrm{Pr}, \mathrm{Nd}$ and gradually decreases towards the heavy rare earth element (HREE) up to 20 times chondrite on Dy, Ho, Er, Tm and Yb elements. The Sebulan spring shows a different pattern from the previous type of water, which shows the value of 0.02-0.08 times chondrite with a $\mathrm{pH}$ of around 7 in both LREE and HREE elements, but the concentration increases up to 0.5 times the chondrite in the Eu element. It also happens as in the downstream of Rio Norquin, the concentration of dissolved REE due to dilution decreases far more than the REE of upstream river water. So that going downstream has an REE pattern with a negative slope across the lanthanide series, while a positive slope across the lanthanide series. This shift in pattern is most likely due to the separation of heavier REE into suspended particles or secondary minerals in streambed [58] However, the positive anomaly Pm in the Banyupait River water sample is likely due to the increase in suspended particles carried during the flow.

\section{Conclusions}

Ijen Volcano was an active stratovolcano that has a large caldera with very acidic crater lakes. $\mathrm{pH}$ 0-1 as magmatic water types $\left(\delta^{18} \mathrm{O}=8.3-8.7 \%\right.$, $\mathrm{D}=-9.4-0.6 \%$ ). The acidic water from the crater lake seeps in the Banyupait River and flowing at the Asembagus region, so the Banyupait River still in a very acidic concentration. The concentration $\mathrm{pH}$ of around 3-7.3 and $\mathrm{SO}_{4}$ levels around 220-683 ppm. But the water river was meteoric $\left(\delta^{18} \mathrm{O}=-5.14--7.68 \%, \mathrm{D}=-46.6--25.5 \%\right)$. Banyupait acidic water is on its way to the estuary experience was mixing with agricultural activities so that the acid water in the eastern part Banyupait contains elements of $\mathrm{Ca}, \mathrm{K}, \mathrm{Mg}$ were lower when compared to the western part Banyupait river water used for agricultural activities. To reduce the concentration of acidity, farmers add acidic water to artesian well water. Acidic water passes through rocks compiled by Ijen volcanic material Pre-caldera consisting of Old Ijen pyroclastic breccia deposits and lahar breccias of Bogor Formation. As a result of the interaction of acidic water, the primary minerals of plagioclase, pyroxene, and groundmass is replaced by chalcedony and hematite.

The plot results of the REE element concentration in the spider diagram generally show a horizontal pattern. The pattern is Banyupait River acid water pattern both in the river flow and in the dilution area with a $\mathrm{pH}$ of around 3-7.3. The LREE concentration was higher than the HREE value, and only the Pm element showed a slightly positive anomaly. In contrast, the zig-zag pattern is a pattern from a spring that is different from the acid water source of the Ijen Crater Lake.

\section{Acknowledgment}

This research was carried out by involving several parties are including the Ministry of Education Indonesia, which had funded this research. Geological Agency (BPPTKG) which has contributed to the provision of secondary data. Hydrogeology and Hydrogeochemistry Laboratory of ITB Bandung, Laboratorium Penelitian dan Pengujian Terpadu of Gajah Mada University Yogyakarta, and Balai Besar Teknik Kesehatan Lingkungan dan Pengendalian Penyakit Yogyakarta which has carried out chemical analysis of water from research samples. Then the Petrology Laboratory of the Department of 
Geological Engineering at UPN Veteran Yogyakarta, which has helped facilitate rock analysis and field activity equipment. For that, thank you to some of these parties, for helping to launch this research activity.

\section{References}

1. Delmelle P, Bernard A (1994) Geochemistry, mineralogy, and chemical modeling of the acid crater lake of Kawah Ijen Volcano, Indonesia. Geochim. Cosmochi Ac 58(11):2445-2460.

2. Sriwana, T., Kadarsetia, E., Sinulingga, I. and Saefudin, A. 1999. Penyelidikan Kimia Air G. Ijen, Jawa Timur. Direktorat Vulkanologi, Tidak Dipublikasikan.

3. Delmelle, P., Bernard, A., Kusukabe, M., Fischer, T.P., Takano, B. 2000. Geochemistry of the magmatic-hydrothermal system of Kawah Ijen volcano East Java, Indonesia, J Volcanol Geotherm Res 2000; 97: 31-53.

4. Takano, B., Suzuki, K., Sugimori, K., Ohba, T., Fazlullin, S.M., Bernard, A., Sumarti, S., Sukhyar, R., and Hirabayashi, M. 2004. Bathymetric and geochemical investigation of Kawah Ijen crater lake, east Java, Indonesia: Journal of Volcanology and Geothermal Research, v. 135, p. 299-329. https://doi.org/10.1016/j.jvolgeores.2004.03.008

5. Caudron, C., Guillaume, M., Williams-Jones, G., Lecocq, T., Syahbana, D.K., de Plaen, R., Peiffer, L., Bernard, A., Saracco, G. 2017. New insights into the Kawah Ijen hydrothermal system from geophysical data, Geological Society London, special publications, January 2016, $\mathrm{http} / / / \mathrm{sp} / 1$ lecollection.org/by quest on January 25, 2016.

6. Sitorus, K. 1990. Volcanic Stratigraphy and Geochemistry of Ijen Caldera complex, East-Java, Unpublished, Master Thesis, Victoria University of Wellington, New Zealand.

7. Van Bemmelen, R.W. 1949. The Geology of Indonesia. Government Printing Office, The Hague.

8. Taverne, N.J.M. 1926. Vulkaanstudien op Java, Vulkan. Med., n. 7, p $99-102$.

9. Scher, S., Williams-Jones, A. E., \& Williams-Jones, G. 2013. Fumarolic activity, acid-sulfate alteration, and high sulfidation epithermal precious metal mineralization in the crater of Kawah Ijen volcano, Java, Indonesia. Economic Geology, 108(5), 1099-1118. https://doi.org/10.2113/econgeo.108.5.1099

10. Neumann van Padang, M. 1951. Catalogue of the active volcanoes of the world including solfatara fields, v.1, Indonesia, p. $156-162$

11. Kusumadinata, K., Hadian R., Hamidi, S., dan Reksowirogo, L., D. 1979. Data Dasar Gunungapi Indonesia, Direktorat Vulkanologi, Direktorat Jenderal Geologi dan Sumberdaya Mineral, Departemen Pertambangan dan Energi, RI.

12. Hochstein, M.P., Sudarman, S. 2015. Indonesian Volcanic Geothermal Systems, Proceedings World Geothermal Congress 2015 Melbourne, Australia, 19-25 April 2015

13. Sitorus, K. 1999. Stratigrafi dan geokimia kaldera Ijen, Jawa Timur, Indonesia, Direktorat Vulkanologi Indonesia, unpublish.

14. Kemmerling GLL (1921) Het Idjen Hoogland de geologie en geomorphologie van den Idjen. de Koninklijke Natuurkundige Vereniging, Batavia

15. Berlo, K. 2001. The magmatic evolution of the Ijen Caldera Complex: Unpublished Ph.D. thesis, Utrecht, Netherlands, Utrecht University, 139 p.

16. Van Hinsberg, V., Berlo, K., Sumarti, S., van Bergen, M., and Williams-Jones, A. 2010a. Extreme alteration by hyper acidic brines at Kawah Ijen volcano, East Java, Indonesia: II. Metasomatic imprint and element fluxes: Journal of Volcanology and Geothermal Research, v. 196, p. 169-184.

17. Carn, S.A. 1999. Application of synthetic aperture radar (SAR) imagery to volcano mapping in the humid tropics: a case study in East Java, Indonesia. Bull. Volcanol. 61(1):92-105.

18. Katili, J.A. 1975. Volcanism and plate tectonics in the Indonesian island arcs: Tectonophysics, v. 26, p. $165-188$.

19. Handley, H.K., Macpherson, C.G., Davidson, J.P., Berlo, K., and Lowry, D. 2007. Constraining fluid and sediment contributions to subduction-related magmatism in Indonesia: Ijen Volcanic Complex: Journal of Petrology, v. 48, p. 1155-1183.

20. Van Hinsberg, V., Vigouroux, N., Palmer, S., Berlo, K., Mauri, G., Williams-Jones, A., Mckenzie, J., Williams-Jones, G., Fischer, T. 2017. Element flux to the environment of the passively degassing crater lake-hosting Kawah Ijen volcano, Indonesia, and implications for estimates of the 
global volcanic flux. Geological Society, London, Special Publications, 437(1), 9-34. https://doi.org/10.1144/SP437.2.

21. Whitford, D.J., Nicholls, I.A., Taylor, S.R. 1979. Spatial variations in the geochemistry of quaternary lavas across the Sunda Arc in Java and Bali. Contrib. Mineral. Petrol. 70, 341-356.

22. Pratama, A., Bijaksana, S., Abdurrachmand, M., Santoso, N.S. 2018. Rock Magnetic, Petrography, and Geochemistry Studies of Lava at the Ijen Volcanic Complex (IVC), Banyuwangi, East Java, Indonesia, Geosciences 2018, 8, 183; DOI:10.3390/geosciences8050183,

23. Caudron, C., Syahbana, D. K., Lecocq, T., Van Hinsberg, V., McCausland, W., Triantafyllou, A., Surono. 2015. Kawah Ijen volcanic activity: a review. Bulletin of Volcanology, 77(3). https://doi.org/10.1007/s00445-014-0885-8.

24. Soeria-Atmadja, R., Maury, R.C., Bellon, H., Pringgoprawiro, H., Polve, M., and Priadi, B. 1994. Tertiary magmatic belts in Java: Journal of SoutheastAsian Earth Sciences, v. 9, p. 13-27

25. Junghuhn, F. 1853. Landschap Banjoewangi en omtreken van den Idjen, Java, II, p.997-1047.

26. Van Hinsberg, V., Berlo, K., van Bergen, M., and Williams-Jones, A. 2010b. Extreme alteration by hyper acidic brines at Kawah Ijen volcano, East Java, Indonesia: I. Textural and mineralogical imprint: Journal of Volcanology and Geothermal Research, v. 198, p. 253-263.

27. Hengeveld, G.J.N. 1920. De mogelijkheid en de plaats van den bouw van een nieuwe sluis bij het kratermeer Kawah Idjen. Mededelingen en rapporten van het departement der burgelijke openbare werken; Geologische onderzoekingen ten behoeve van 's lands waterstaat-, gewestelijke- en gemeentewerken in Neder- landsch-Indie, Weltevreden, pp. 93-118.

28. Sriwana, T., \& Kadarsetia, E. 2010. Kimia Air Danau Kawah Gunung Ijen Dan Sekitarnya - Jawa Timur, Menjelang Letusan Tahun 1999 Chemistry of the Crater Lake of Ijen Volcano and Surrounding Area, East Java, Prior To 1999 Eruption. 5(June 1999), 19-23.

29. Katili, J.A. 1979. Data Dasar Gunungapi Indonesia, Catalogue of References on Indonesian Volcanoes with Eruption in historical time, Republik Indonesia Departemen Pertambangan dan Energi Direktorat Jendral Pertambangan Umum Direktorat Vulkanologi, p.360-371.

30. Venzke, E., Wunderman, R.W., McClelland, L., Simkin, T., Luhr, J.F., Siebert, L., Mayberry, G., and Sennert, S., eds. 2012. Global volcanism, 1968 to the present: Smithsonian Institution, Global Volcanism Program Digital Information Series, GVP-4, http:/www.volcano.si.edu/reports/.

31. Badan Geologi 2014. G. Ijen, Jawa Timur, http://www.vsi.esdm.go.id/index.php/gunungapi/datadasar-gunungapi/522-g-ijen

32. Badan Geologi 2018. Press Release: Aktivitas Gunungapi Ijen, Jawa Timur Terkait Kejadian Gas Beracun Di Kampung Watucapil, http://www.vsi.esdm.go.id/index.php/gunungapi/aktivitas-gunungapi/2084-press-release-aktivitas-gunungapi-ijen-jawa-timur-terkait-kejadian-gas-beracun-di-kampung-watucapilsempol.

33. Vigouroux-Caillibot, N., 2011, Tracking the evolution of magmatic volatiles from the mantle to the atmosphere using integrative geochemical and geophysical methods: Unpublished Ph.D. thesis, Vancouver, Canada, Simon Fraser University, 265 p.

34. Schmidt, F. H dan Ferguson, J. H. A. 1951. Rainfall Types Based On Wet and Dry Period Rations for Indonesia with Western New Guinea. Jakarta: Kementrian Perhubungan Meteorologi dan Geofisika.

35. Agustiyanto and Santoso 1993. Peta Geologi Lembar Situbondo, Jawa, Pusat Peneltian dan Pengembangan Geologi Bandung.

36. Zelenov, K. K. 1969. Aluminium and titanium Kava Ijen volcano crater lake, International geological review, Res. 11: 84-93.

37. Wittiri, S.R. and Sumarti, S. 2010. Kawah Ijen Penghasil Belerang Terbesar. Pusat Vulkanologi dan Mitigasi Bencana Geologi, Kementrian Energi dan Sumber Daya Mineral. Di akses pada $<$ http://esdm.go.id/berita/56-artikel/3509-kawah-ijen-penghasil-belerang-terbesar.html>.

38. Aminuddin and Andiani 2015. Ancaman Air Asam Kawah Ijen, Artikel Geologi Populer, Artikel Geologi Populer 23 Okt 2015, http://geomagz.geologi.esdm.go.id/ancaman-air-asam-kawah-ijen/

39. Richardson, S.M., dan McSween, H.Y.Jr. 1989. Geochemistry Pathways and Processes, Englewood Cliffs, New Jersey, 208-235.

40. Craig, H. 1961. Isotopic Variations in Meteoric Waters, Science 133, 1702-1703. 
41. Craig, H. 1966. Isotopic Composition and Origin of the Red Sea and Salton Sea Geothermal Brines: Science, 154, 1544-1548.Delmelle, P., and Bernard, A. 1994. Geochemistry, mineralogy, and chemical modeling of the acid crater lake of Kawah Ijen volcano, Indonesia: Geochimica et Cosmochimica Acta, v. 58, p. 2445-2460.

42. Johannesson, K.H., Lyons, W.B., 1995. Rare-earth element geo- chemistry of Colour Lake, an acidic freshwater lake on Axel Heiberg Island, Northwest Territories, Canada. Chem. Geol. 119, 209-223.

43. Leybourne, M.I., Goodfellow, W.D., Boyle, D.R., Hall, G.M., 2000. Rapid development of negative $\mathrm{Ce}$ anomalies in surface waters and contrasting REE patterns in groundwaters associated with $\mathrm{Zn}-\mathrm{Pb}$ massive sulphide deposits. Appl. Geochem. 15, 695-723.

44. Wood, S.A., Shannon, W.M., Baker, L., 2005. The aqueous geo- chemistry of the rare earth elements and yttrium. Part 13. REE geochemistry of mine drainage from the Pine Creek area, Coeur d'Alene River Valley, Idaho, USA. In: Johannesson, K.H. (Ed.), Rare Earth Elements in Groundwater Flow Systems, Water Sci. Technol. Libr., vol. 51. Springer, Dordrecht, The Netherlands, pp. 89-110.

45. Kikawada, Y., Oi, T., Honda, T., Osaka, T., Kakihana, H. 1993. Lanthanoid abundances of acidic hot spring and crater lake waters in the Kusatsu-Shirane volcano region, Japan. Geochem. J. 27, 19-33.

46. Kikawada, Y., Oi, T., Honda, T. 1999. Lanthanoid abundance in some neutral hot spring waters from Japan. J. Balneol. Soc. Jpn. 49, 8-17.

47. Kikawada, Y., Oi, T., Osaka, T., Kakihana, H., Honda, T. 1995. Leaching of lanthanoids from andesitic rocks by acidic aqueous solutions. Geochem. J. 29, 67-84.

48. Huang S.J., Huang K.K., Feng W.L., 2009. Mass exchange among feldspar, kaolinite and illite and their influences on secondary porosity formation in clastic diagenesis: A case study on the Upper Paleozoic, Ordos Basin and Xujiahe Formation, Western Sichuan Depression. Geochimica, 2009, 38 (5): 498-506 (in Chinese with English abstract).

49. Steefel C.I., Maher K., Fluid-rock interaction: A reactive transport approach. Reviews in Mineralogy and Geochemistry, 2009, 70(1): 485-532.

50. Liu, S., Chen, A., Shen, Z., Zhengxiang L., and Zhang, X., 2018. Fluid-rockinteraction and dissolution of feldspar in the Upper Triassic Xujiahe tight sandstone, western Sichuan Basin, China, Geosci.2018;10:234-249.

51. Zulkarnain, I., 1991. Lingkungan Fisika-Kimia Zona Alterasi Endapan Tembaga Porfiri dengan Kasus Daerah Saar-Nahe, Jerman, Riset Geologi dan Pertambangan LIPI, p.22-21.

52. Rowe, G.L. Jr., Brantley, S.L., Fernandez, M., Fernandez, J.F., Barquero, J., Borgia, A., 1992. Fluid-volcano interactions at an active stratovolcano: The crater lake system of Poas Vol- cano, Costa Rica. J. Volcanol. Geotherm. Res. 49, 23-51

53. Rowe, G.L. Jr., Brantley, S.L., Fernandez, J.F., Borgia, A., 1995. The chemical and hydrologic structure of Poas Volcano, Costa Rica. J. Volcanol. Geotherm. Res. 64, 233-267.

54. Pasternack, G.B., Varekamp, J.C., 1994. The geochemistry of the Keli Mutu crater lakes, Flores, Indonesia. Geochem. J. 28, 243-262.

55. Sriwana, T., Van Bergen, M. J., Sumarti, S., De Hoog, J. C.M., Van Os, B. J.H., Wahyuningsih, R., Dam, M. A.C., 1998. Volcanogenic pollution by acid water discharges along Ciwidey River, West Java (Indonesia), ournal of Geochemical Exploration 62 (1998) 161-182.

56. Symonds, R.B., Rose, W.I., Reed, M.H., Lichte, F.E., Finnegan, D.L., 1987. Volatilization, transport and sublimation of metal- lic and non-metallic elements in high temperature gases at Merapi Volcano, Indonesia. Geochim. Cosmochim. Acta 51, 2083-2101.

57. Brantley, S.L., Borgia, A., Rowe, G., Fernandez, J.F., Reynolds, J.R., 1987. Poas volcano crater lake acts as a condenser for acida metal-rich brine. Nature 330, 470-472.

58. Gammons, C.H., Wood, S.A., Pedrozo, F., Varekamp, J.C., Nelson, B.J., Shope, C.L., Baffico, G., 2005. Hydrogeochemistry and rare earth element behavior in a volcanically acidified watershed in Patagonia, Argentina, Chemical Geology 222 (2005), p.249-267. 
Table 3. Results of the REE analysis of the study area and the REE results conducted by [4].

\begin{tabular}{|c|c|c|c|c|c|c|c|c|c|c|c|c|c|c|c|c|}
\hline \multirow{3}{*}{ 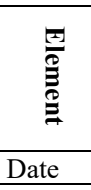 } & \multirow{3}{*}{ 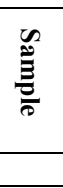 } & \multicolumn{5}{|c|}{ [4] } & \multirow{3}{*}{$\begin{array}{l}\text { ST5-d/R } \\
28-A p r \\
\end{array}$} & \multirow{2}{*}{\multicolumn{2}{|c|}{$\begin{array}{c}\text { ST9-c/R } \quad \text { ST10-b/R } \\
\text { River }\end{array}$}} & \multirow{4}{*}{\begin{tabular}{|l|} 
ST26-R \\
\\
$30-\mathrm{Apr}$ \\
12.7426 \\
\end{tabular}} & \multirow{3}{*}{\begin{tabular}{|l|} 
ST53-c/R \\
Beach well \\
$29-A p r$ \\
\end{tabular}} & \multirow{3}{*}{\multicolumn{2}{|c|}{$\begin{array}{l}\begin{array}{l}\text { ST18-b/R } \\
\text { b) }\end{array} \\
\text { RT38-c/R } \\
\text { River } \\
\text { 1 May } \\
\end{array}$}} & \multirow{4}{*}{\multicolumn{2}{|c|}{$\begin{array}{lc}\text { ST54-R } & \text { ST39-R } \\
& \text { Estuarine } \\
2 \text { May } & \text { 2 May } \\
1.6892 & 3.3281 \\
\end{array}$}} & \multirow{4}{*}{$\begin{array}{l}\text { ST4-R } \\
\text { Spring } \\
3 \text { May } \\
65.2248\end{array}$} \\
\hline & & \multirow[t]{2}{*}{$\mathbf{0 ~ m}$} & ${ }^{25} \mathrm{Cr}$ & \multicolumn{2}{|c|}{$\begin{array}{l}50 \\
\text { iter water }\end{array}$} & \multirow[t]{2}{*}{82} & & & & & & & & & & \\
\hline & & & & & & & & 30-Apr & 30-Apr & & & & & & & \\
\hline $\mathrm{V}$ & & 12.1 & 12 & 12.2 & 12.3 & 12.1 & 2.8662 & 27.8978 & 0.4423 & & 99.3019 & 1.5842 & 6.4243 & & & \\
\hline $\mathrm{Cr}$ & & 247 & 331 & 295 & 302 & 304 & 1.3441 & 1.0119 & 1.2220 & 1.5920 & 2.3710 & 1.7228 & 2.0926 & 2.4429 & 1.3762 & 0.8975 \\
\hline Mn & & 49.4 & 50.6 & 51.5 & 52.6 & 53.2 & 121.0185 & 8.4864 & 260.7941 & 1036.1196 & 488.8558 & 496.5489 & 489.5964 & 496.5582 & 307.3416 & 0.1725 \\
\hline $\mathrm{Fe}$ & & 2330 & 2400 & 2400 & 2440 & 2450 & 172.3954 & 80.5545 & 32.2760 & 41.8277 & 17343.3207 & 3064.8910 & 6280.2041 & 3111.8384 & 118.0632 & 7.2165 \\
\hline Co & & 476 & 454 & 471 & 456 & 451 & 0.5670 & 0.0821 & 2.3130 & 2.5382 & 5.6727 & 5.8002 & 5.5890 & 5.2648 & 2.7067 & 0.0168 \\
\hline $\mathrm{Ni}$ & & 242 & 499 & 428 & 501 & 534 & 1.0719 & 0.5960 & 1.1512 & 1.8660 & 3.8679 & 3.6564 & 3.9481 & 4.0006 & 2.8807 & 0.7955 \\
\hline $\mathrm{Cu}$ & & 336 & 347 & 366 & 399 & 354 & 1.3481 & 0.8685 & 0.6082 & 0.5895 & 6.9884 & 6.0535 & 6.3073 & 5.1909 & 1.8616 & 0.2537 \\
\hline $\mathrm{Zn}$ & & 72 & 76.2 & 73.8 & 72.6 & 76.8 & 1.3581 & 15.6011 & 7.6147 & 4.3138 & 65.2250 & 52.4817 & 55.5554 & 39.5808 & 10.4800 & 227.2149 \\
\hline $\mathrm{Ga}$ & & 1109 & 1076 & 1107 & 1083 & 1088 & 0.1225 & 0.0377 & 0.0311 & 0.0607 & 7.7535 & 2.3061 & 3.6976 & 2.5414 & 0.5541 & $<0.000$ \\
\hline As & & 1660 & 1550 & 1640 & 1610 & 1610 & 2.0575 & 1.5416 & 1.2424 & 1.4073 & 7.5525 & 1.6393 & 1.6973 & 1.0928 & 0.1435 & 2.2132 \\
\hline $\mathrm{Rb}$ & & 4000 & 3900 & 4060 & 3970 & 4000 & 8.8053 & 9.5434 & 13.6106 & 25.4297 & 29.2001 & 27.7937 & 28.7739 & 33.6364 & 49.7487 & 9.3527 \\
\hline $\mathrm{Sr}$ & & 17.3 & 16.1 & 16.9 & 16.4 & 17.1 & 96.1302 & 166.9835 & 145.0570 & 972.3067 & 942.4733 & 860.7520 & 928.8451 & 1409.7965 & 7843.3004 & 447.0924 \\
\hline $\mathrm{Y}$ & & 1230 & 1170 & 1150 & 1160 & 1150 & 1.2157 & 0.1418 & 0.4648 & 0.2424 & 34.6369 & 30.3834 & 29.8390 & 39.4799 & 53.7790 & 0.0176 \\
\hline $\mathrm{Cd}$ & & 57.1 & 55.7 & 57.6 & 57.1 & 55.9 & 0.0291 & 0.0048 & 0.0522 & 0.0819 & 0.5388 & 0.4208 & 0.4551 & 0.3849 & 0.1335 & 0.1993 \\
\hline $\mathrm{Ba}$ & & 275 & 240 & 251 & 217 & 270 & 48.7390 & 33.9170 & 21.1929 & 54.1833 & 70.4044 & 66.3713 & 62.6900 & 93.6329 & 100.9594 & 30.2435 \\
\hline $\mathrm{La}$ & & 1030 & 990 & 984 & 990 & 1010 & 0.4095 & 0.0579 & 0.2739 & 0.1114 & 19.9420 & 16.6028 & 16.9008 & 21.6084 & 32.3326 & 0.0058 \\
\hline $\mathrm{Ce}$ & & 2530 & 2430 & 2410 & 2430 & 2490 & 0.7219 & 0.1250 & 0.4728 & 0.1906 & 50.1055 & 40.8971 & 40.7143 & 52.0973 & 68.7157 & 0.0115 \\
\hline $\operatorname{Pr}$ & & 313 & 300 & 300 & 300 & 307 & 0.1712 & 0.0156 & 0.0623 & 0.0298 & 8.0308 & 6.6944 & 6.5933 & 8.7720 & 12.2335 & 0.0070 \\
\hline $\mathrm{Nd}$ & & 1440 & 1370 & 1380 & 1380 & 1410 & 0.7458 & 0.0949 & 0.3165 & 0.0835 & 33.3484 & 27.3721 & 28.3773 & 35.1799 & 44.1153 & 0.0092 \\
\hline $\mathrm{Sm}$ & & 311 & 297 & 298 & 301 & 305 & 0.1902 & 0.0319 & 0.0717 & 0.0254 & 7.2541 & 6.0464 & 6.5816 & 7.3964 & 7.8779 & 0.0086 \\
\hline $\mathrm{Eu}$ & & 68.7 & 66.2 & 65.8 & 66.1 & 67.2 & 0.0786 & 0.0294 & 0.0325 & 0.0306 & 2.0225 & 1.7680 & 1.8693 & 2.2303 & 2.1328 & 0.0246 \\
\hline $\mathrm{Gd}$ & & 296 & 287 & 288 & 291 & 293 & 0.1978 & 0.0191 & 0.0674 & 0.0308 & 6.9848 & 6.2384 & 6.6445 & 7.4714 & 7.5986 & 0.0030 \\
\hline Dy & & 269 & 263 & 263 & 264 & 265 & 0.1809 & 0.0245 & 0.0661 & 0.0337 & 6.4884 & 5.6721 & 5.9711 & 7.4485 & 8.1328 & 0.0039 \\
\hline Ho & & 38.3 & 36.9 & 37.2 & 37.1 & 37.3 & 0.0465 & 0.0074 & 0.0132 & 0.0074 & 1.3150 & 1.1015 & 1.1257 & 1.4132 & 1.6964 & 0.0032 \\
\hline Er & & 150 & 146 & 147 & 146 & 149 & 0.1498 & 0.0128 & 0.0445 & 0.0164 & 4.0898 & 3.6283 & 3.7688 & 4.4767 & 5.1961 & 0.0041 \\
\hline
\end{tabular}




\begin{tabular}{|c|c|c|c|c|c|c|c|c|c|c|c|c|c|c|c|}
\hline $\mathrm{Tm}$ & 4.1 & 3.7 & 4.3 & 4 & 3.6 & 0.0287 & 0.0036 & 0.0076 & 0.0027 & 0.4976 & 0.4474 & 0.4615 & 0.5546 & 0.6318 & 0.0033 \\
\hline $\mathrm{Yb}$ & 132 & 129 & 128 & 128 & 131 & 0.1510 & 0.0118 & 0.0497 & 0.0184 & 3.3388 & 3.0091 & 3.2538 & 3.7957 & 3.6276 & 0.0041 \\
\hline $\mathrm{Tl}$ & 786 & 773 & 799 & 786 & 789 & 0.1288 & 0.6438 & 0.6929 & 0.8748 & 1.1661 & 1.1702 & 2.2068 & 3.8739 & 7.5036 & 0.1076 \\
\hline $\mathrm{Pb}$ & 4290 & 4200 & 4370 & 4280 & 4350 & 0.0013 & 2.2834 & 0.4091 & 0.3259 & 22.7502 & 8.1107 & 11.8436 & 10.7349 & 5.3317 & 1.2886 \\
\hline U & 51 & 50 & 53 & 52 & 54 & 0.0272 & 0.0765 & 0.0097 & 0.2113 & 1.5495 & 1.0962 & 1.1989 & 1.4716 & 6.7842 & 0.8283 \\
\hline
\end{tabular}

\begin{tabular}{llll} 
& & & \\
& & & \\
& & & \\
& & & \\
\hline .4615 & 0.5546 & 0.6318 & 0.0033 \\
938 & 3.7957 & 3.6276 & 0.0041 \\
.068 & 3.8739 & 7.5036 & 0.1076 \\
9436 & 10.7349 & 5.3317 & 1.2886 \\
989 & 1.4716 & 6.7842 & 0.8283 \\
\hline
\end{tabular}

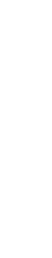

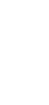

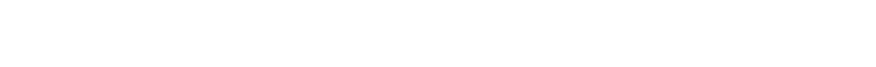

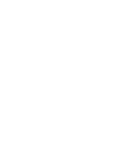

ran

